Policy Research Working Paper 2997

\title{
Financial and Legal Institutions and Firm Size
}

\author{
Thorsten Beck \\ Aslı Demirgüç-Kunt \\ Vojislav Maksimovic
}

The World Bank

Development Research Group

Finance

March 2003 


\begin{abstract}
Beck, Demirgüç-Kunt, and Maksımovıc investigate how a country's financial institutions and the quality of its legal system explain the size attained by its largest industrial furms in a sample of 44 countries. Firm size is positively related to the size of the banking system and the efficiency of the legal system. Thus, the authors find no evidence that firms are larger in order to internalize the
\end{abstract}

functions of the bankıng system or to compensate for the general inefficiency of the legal system. But they do find evidence that externally financed firms are smaller in countries that have strong creditor rights and efficient legal systems. This suggests that firms in countries with weak creditor protections are larger in order to internalize the protection of capital investment.

This paper-a product of Finance, Development Research Group-1s part of a larger effort in the group to understand the determınants of firm size. Copies of the paper are available free from the World Bank, $1818 \mathrm{H}$ Street NW, Washıngton, DC 20433. Please contact Karı Labrie, roomMC3-456, telephone 202-473-1001, fax 202-522-1155, email address klabrie@worldbank.org. Policy Research Working Papers are also posted on the Web at http://econ.worldbank.org. The authors may be contacted at tbeck@worldbank.org or ademirguckunt@worldbank.org. March 2003. (46 pages)

The Poltcy Research Working Paper Senes disseminates the findings of work in progress to encourage the exchange of ideas about development issues. An objective of the series is to get the findings out quickly, even if the presentations are less than fully polished. The papers carry the names of the authors and should be cited accordingly. The findings, interpretations, and conclustons expressed in this paper are entrely those of the authors. They do not necessarly represent the view of the World Bank, its Executtve Directors, or the countries they represent 


\title{
FINANCIAL AND LEGAL INSTITUTIONS
}

\author{
AND FIRM SIZE
}

\author{
Thorsten Beck, Ashı Demirgüç-Kunt and Vojislav Maksimovic
}

Keywords: Financial Development; Financing Obstacles, Small and Medium Enterprises, Law and Finance

JEL Classification: G30, G10, O16, K40

Beck and Demirgulç-Kunt: World Bank; Maksimovic: Robert H. Smith School of Business at the University of Maryland. 



\section{Introduction}

A rapidly growing literature, originating with LLSV (1998), has demonstrated the importance of the legal system and financial institutions for firms' financial decisions, such as capital structure and dividend policy. ${ }^{1}$ For the most part, this literature treats the firm size as given. However, financial intermediaries and the legal system provide an alternative way of accomplishing some of the key functions that the firm accomplishes internally: the mobilization of resources for investment, the monitoring of performance, and resolution of conflicts of interest among different parties. As a result, the equilibrium size of firms might also depend on the development of these institutions in each country. In this paper, we investigate empirically the relation of firm size and the development of financial institutions and legal protection of investors in different countries.

The corporate finance literature suggests that the financial and legal institutions could affect firm size in opposing ways. First, several papers suggest that in countries with less developed legal systems and financial systems firm growth is constrained by their ability to obtain external finance (Demirguc-Kunt and Maksimovic (1998) and Rajan and Zingales (1998)). Beck, Demirguc-Kunt and Maksimovic (2002) find that small firms in countries with weak financial systems report facing more obstacles to growth than large firms. In such countries large firms' internal capital markets are likely to be more effective at allocating capital and monitoring individual investment projects than the public markets and financial institutions. As a result, firms in countries with weak legal and institutional systems have an incentive to substitute internal capital markets for public markets. This substitution suggests an inverse relation between firm size and the development of a country's legal system and financial institutions.

\footnotetext{
${ }^{1}$ See LLSV (2000) and Harvey and Rouwenhurst (2002) for an overview of this literature.
} 
However, there may also be an opposing effect at work. Large firms are also subject to agency problems. Their size and complexity makes expropriation by firms' insiders difficult to monitor and control by outside investors. Thus, investors in large firms may require strong financial institutions and effective legal systems to control expropriation by corporate insiders. As a result, the optimal size of firms may be positively related to the quality of a country's legal system and financial institutions.

We investigate empirically the relation between firm size and the development of financial institutions and legal protection of investors in 44 countries. We find that there exists a positive relation between the level of development of a country's banking system and firm size. This relation remains strong even after controlling for the size of the economy and national income per capita. There also exists a somewhat weaker relation between firm size and the capitalization of the stock market. These results are stronger for firms that depend on external finance. Moreover, firms in countries with concentrated banking systems, which provide incentives for bank monitoring and long term relationships with borrowers, are also larger.

We also find significant relations between a country's legal system and firm size. Large firms are larger in countries with more efficient legal systems. This effect is strongest for firms that rely on external financing. However, when we consider specific legal rights of creditors we do find evidence of a negative relation between firm size and creditors' rights. This effect is strongest when the legal system is efficient and for firms that depend on external financing. Thus, we do find evidence that weak creditor protections, holding all other factors constant, create incentives for increasing firm size in order to internalize the allocation of capital.

We also test for firm characteristics and country characteristics other than the legal and financial system as determinants of firm size. We find that firm size is positively related to the 
ratio of the firm's fixed assets to total assets, suggesting that there are economies of scale in operating capital-intensive businesses. By contrast, firm profitability and sales turnover do not predict firm size. The largest firms tend to be larger in countries with high per capita incomes, but the firm size is not related to human capital, as measured by secondary school enrollment in the country. Interestingly, the openness of an economy to foreign trade and competition is not related to firm size once the other explanatory variables are held constant.

Our paper is related to the newly emerging literature on the role of financial and legal institutions on firm performance. LLSV (1997, 1998), Demirguc-Kunt and Maksimovic (1998), and Rajan and Zingales (1998) show that developed financial systems and the efficient enforcement of laws facilitate external funding of firms. These papers take the distribution of firm sizes as exogenous. By contrast, we allow for the possibility that firm organization may adjust in response to the level of development of institutions and show that firm size and both the development of the banking sector and the general enforcement of laws are complements.

Our paper is also related to two recent papers by Kumar, Rajan and Zingales (2001) and Cetorelli (2002). While Kumar, Rajan and Zingales also examine the determinants of firm size across countries, their approach statistically infers firm sizes in different countries from aggregate industry data in each country they consider. By contrast, we obtain our data from financial reports, and also focus on legal determinants of firm size. Cetorelli (2002) uses industry-level data for 17 OECD countries to assess the effect of bank concentration on industrial concentration. He, however, uses the average firm size for an industry rather than firm-level data, as we do. 
The remainder of the paper is organized as follows. In Section 2 we discuss the hypotheses that we test. Section 3 discusses the data and our empirical methodology. Section 4 presents our main results. Section 5 concludes. Data sources are discussed in the Appendix.

\section{Motivation}

The key question in analyzing firm size was posed by Coase (1937): "Why does the boundary of the firm and the market fall where it does?" Coase argued that certain productive tasks are optimally done within firms, where actions of subordinate managers can be optimally monitored, but that with increasing size firms become inefficient. As a firm grows, there comes a point where it reaches equilibrium size where the benefits of size are balanced by the costs. The equilibrium size for each firm depends on its organizational capital, or in the case of entrepreneurial firms, on the abilities of the entrepreneur (Lucas (1978), Maksimovic and Phillips (2002)). However, little is known about how the functioning of financial institutions and legal systems in a country affects this balance and how the equilibrium firm size varies across countries. We next examine how such an impact could arise.

\section{a. Internal Monitoring, Access to Capital and Firm Size}

There are at least two ways that state of a country's financial and legal institutions can determine whether it is more efficient to organize an activity as a small stand-alone firm, or as a unit of larger firm. ${ }^{2}$ At the project level, depending on the state of country's financial and legal institutions, it may be more efficient to monitor projects internally in a firm rather than using the

\footnotetext{
${ }^{2}$ See Stein $(1997,2002)$ for an analysis of the role of information flows in the organization of firms.
} 
capital market. At the firm level, access to capital markets may also depend on the size of the firm.

A firm's internal capital allocation process in certain respects functions more efficiently than a public capital market. Firms are hierarchies, and senior managers can command managers in charge of a project to produce information, and provide finely calibrated incentive schemes. In the event it becomes necessary, the firm's senior management can seize direct control of a nonperforming unit and liquidate its assets. These advantages of internal allocation of resources are particularly valuable in economies without effective external monitoring by financial intermediaries or a legal system that can safeguard creditors' claims on assets. ${ }^{3}$

As shown by Demirguc-Kunt and Maksimovic (1998), firms in countries with less efficient legal and financial systems have less access to external financing. It is likely that the advantages to having an internal capital market would be the highest in those countries. Large firms have the advantage of a large internal capital market. Whereas a small firm that produces a limited range of products might have to access public capital markets repeatedly in order to finance new projects, a large firm may be able to self-finance by shifting capital from mature projects to projects that are at the investment stage. Thus, the firm can avoid adverse selection costs that arise when firms obtain capital from outside investors who are less informed than the firm's managers about the value of the firm's assets.

Empirical evidence in Beck, Demirguc-Kunt and Maksimovic (2002) shows that small firms in countries with weak financial and legal systems face significant obstacles to growth as a result of poor relationships with banks, in some cases due to perceived corruption of bank officials, and poor legal protections. Large firms face less significant obstacles. This evidence suggests that in

\footnotetext{
${ }^{3}$ As Fluck (1999) points out, some projects that may be subject to the agency costs if financed on a standalone basis, particularly when renegotiation is costly, become viable as part of a larger corporation.
} 
countries with weak financial and legal systems large firms have a comparative advantage in financing and monitoring individual investment projects. If this conjecture is valid and the effect material, we would expect that, holding other variables constant, the equilibrium firm size is smaller in countries with efficient legal systems and well-developed financial systems.

However, advantages to size might be offset if insiders of large firms can expropriate more investor wealth in countries with weak institutions. In this case, the low quality of external monitoring or the inability of external investors to prevent misappropriation acts as a cost to size. A firm in a country with significant agency costs of size may mitigate those costs by, for example, remaining under family control, perhaps at the cost of reduced operational effectiveness. As a result, the negative relation between the equilibrium size and the quality of a country's institutions will not hold if large firm' insiders have a sufficiently large comparative advantage in expropriating assets in countries with weak financial and legal systems.

There is little empirical evidence on how the ability of managers to expropriate wealth varies with the quality of a country's institutions and the ability to allocate resources using a firms' internal capital market. However, evidence on a related question, whether in a single country firms which are organized so that managers have discretion to shift funds across divisions are subject to greater agency costs than single-division firms, suggests that there might exist a similar relation between weak external monitoring that permits managerial discretion and value dissipation. Studies using U.S. data by Lang and Stulz (1994) and Berger and Ofek (1995) show that when managers can allocate funds across industries in multi-divisional firms, the value of the firms declines relative to a single-segment firm benchmark. Comment and Jarrell (1995) 
document that stock market returns to conglomerate firms are lower than that to single-segment firms. ${ }^{4}$

The foregoing discussion suggests that if external monitoring is more important in reducing dissipation in larger firms, then holding other variables constant, the equilibrium firm size is larger in countries with efficient legal systems and well-developed financial systems. Below we examine this conjecture empirically.

\section{b. The Structure of the Banking System and Firm Size}

We expect that the equilibrium firm size is smaller if the banking system in their country is configured in ways that minimize the informational differences between small firms' insiders and their banks. As shown by Petersen and Rajan (1995), banks with market power have greater incentives to establish lending relationships with smaller firms since they can recoup the costs of acquiring information about the firms over the long term. ${ }^{5}$ As a result, we expect that equilibrium firm size is smaller in countries with concentrated banking systems. On the other hand, banks in concentrated banking systems may have very close relationship with large incumbent firms, so that we might find a positive relation between firm size and bank concentration. ${ }^{6}$ Below we test whether, holding other variables constant, the equilibrium firm size is smaller or larger in countries with concentrated banking systems.

\footnotetext{
${ }^{4}$ Berger and Ofek (1995) and Comment and Jarrell (1995) explain their findings by appealing to agency theories that predict a misallocation of capital as firms allocate capital to segments that are underperforming. Rajan, Servaes, and Zingales (2000). Maksimovic and Phillips (2002) provide evidence that investment allocations of conglomerates across divisions in the U.S. are broadly consistent with optimal resource allocation, suggesting that the value dissipation is not due to misallocation across projects, but might occur at either at the headquarters level or at peripheral segments with lower productivity. ${ }_{5}^{5}$ Marquez (2000), and Cetorelli and Peretto (2000) also argue that bank screening of customers is more intense in concentrated banking markets. Dinç (2000) argues that while the amount of screening initially increases with concentration of the banking market, beyond a certain level concentration may decrease the amount of screening. Beck, Demirguc-Kunt and Maksimovic (2003) find that concentrated banking systems are associated with higher financing obstacles and lower probability of access to bank finance for firms.
} 
We also examine whether state control of banks affects optimal firm size. State control of banks is a potentially important factor because, as shown by La Porta, Lopez-de-Silanes and Shleifer (2001), such banks are in general less efficient in allocating resources to productive uses than private banks. If state-controlled banks act less efficient than private banks, we would expect state control of a country's banking system to have the same impact on firm size as a reduction in the size of the banking sector. We test this conjecture below.

\section{c. Investor Protections and Firm Size}

In addition to examining the relation between the efficiency of the legal system and firm size, we also examine the relation between specific investor protections and firm size. We expect that investors have more incentives to be, and are more efficient as, monitors of loans in countries that effectively protect investors' rights. Hence, we would expect less reliance on internal capital markets in these countries. However, strong investors' protections might also permit banks to lend to large firms that would otherwise be subject to agency costs. Finally, the Critical Resource Theory (Grossmann and Hart, 1986) predicts that the quantity of assets over which ownership can be exerted, determines firm size. This would also point to the efficiency of the legal system as positively influencing firm size across countries. Which of these effects predominates is an empirical question, and we test whether, holding other variables constant, the equilibrium firm size is smaller or larger in countries that effectively protect investors' rights.

\section{d. Technology, the Market and Firm Size}

Optimal firm size also depends on the firm's technology and on its market opportunities (You, 1995). We control for several of the factors identified in the literature. We expect capital intensity to be positively related to size. Firms in large markets and open economies may be able

\footnotetext{
${ }^{6}$ Lamoreaux (1991) shows that in $19^{\text {th }}$ century New England "kinship networks" regulated lending flows to entrepreneurs, while Haber (1991) finds a similar pattern for the Mexican banking system of the late $19^{\text {th }}$
} 
to take advantage of economies of scale not available in small markets and economies that have been less affected by globalization.

In our analysis we also control for indicators of a country's economic development, specifically its Gross Domestic Product per capita and the educational level of its population. These control variables reduce the risk that the institutional and legal variables we use are proxying for other factors that depend on a country's level of development. Richer economies should have larger firms, since potential entrepreneurs face higher opportunity costs in the form of higher wages (Lucas, 1978). A higher level of human capital in an economy might either enable larger firms, due to higher managerial skills, or more and thus smaller firms, due to more wide-spread entrepreneurial skills (Lucas, 1978; Rosen, 1982 and Kremer, 1993).

We also include each firm's return on assets in our equations explaining firm size. A persistent and systematic relation between firm size and return on assets might indicate that the distribution of firm sizes in our sample is in disequilibrium, with a systematic mismatch between benefits and costs of size. In addition, in some of the tests below we focus on firms with an external financing need. If, as we conjecture, firm size depends on the development of financial institutions, the size of firms that depend most on external financing is likely to be more sensitive to differences in institutions across countries.

\section{e. Data on Firm Size}

Consistent data on the complete distribution of firm sizes across a representative sample of developed and developing countries is not available. In their study, Kumar, Rajan and Zingales (2001) infer representative firm sizes in each country from industry-level data. This approach is contingent on their ability to model the distribution of firm sizes in each country. Cetorelli (2002) uses the average firm size on the industry level. By contrast, we use firm-level data 
directly. Firm-level data is only available for the largest firms in each country. In common with most of the literature, due to data limitations we focus on the largest firms in each country. ${ }^{7}$. The tradeoffs between the advantages and disadvantages of size outlined above pertain to all firms in an economy, and specifically to the subsample of largest firms. However, in interpreting our results it is important to bear in mind that these tradeoffs may not be as relevant for very small firms, many of whom may not have access to external financing of from financial intermediaries.

Below we use firm-level data for 44 countries to answer the following questions:

- Are the largest firms in countries with the well-developed financial systems bigger or smaller than the largest firms in countries with less developed financial systems?

- Is there a positive or negative relation between firm size and the efficiency of the legal system?

- Are strong shareholder and creditor protections positively or negatively related to firm size?

- Is a concentrated banking system associated with the existence of larger or smaller firms?

- Is state control of the banking system associated with the existence of larger or smaller firms?

\footnotetext{
${ }^{7}$ See, for example, LLSV (1999) on ownership concentration or Demirguc-Kunt and Maksimovic (1998, 1999) on capital structure.
} 


\section{Data and Methodology}

\subsection{Data}

We have annual data, for the period 1988-97, available for 44 countries, both developing and developed. To make the sample of firms comparable across countries, we focus on the top 100 manufacturing companies, where available. ${ }^{8}$ This section describes the data and its sources, discusses descriptive statistics and explains the methodology that we employ. ${ }^{9}$ Table 1 lists the economic and institutional indicators for the 44 countries in our sample, averaged over the sample period 1988-97. Table 2 provides descriptive statistics and correlations of all variables.

The firm-level data are drawn from financial statements by large publicly traded companies, collected by Worldscope. We use total assets of a firm, relative to GBP or in constant U.S. dollars as dependent variable, and several other firm-specific characteristics as potential determinants of firms size.

We use the share of a firm's total assets in its country's GDP as our main indicator of firm size. This indicates the firm's size relative to the total output of an economy. This indicator directly measures the proportion of a country's output produced within the firm, and can thus be related to the institutional differences across countries. In our sensitivity analysis we also use a firm's total assets in constant U.S. dollars as indicator of firm size. While not relating a firm size to its country's economy, this indicator makes firm size directly comparable across countries. As can be seen in Table 2, there is a wide variation in firm size, both as measured by Assets/GDP and by Assets in U.S. dollars. Both measures are positively and significantly correlated.

We use three firm-specific characteristics as explanatory variables. We use the Net Fixed Assets divided by total assets to explore whether the structure of a firm's assets can explain its

\footnotetext{
${ }^{8}$ See Appendix Table 1 for number of firms in each countries and number of observations.
} 
size. A firm with a larger share of fixed assets in total assets has more collateral, thus larger borrowing power and should therefore be better able to expand its operation using external finance. A larger share of fixed assets might also indicate a larger capital intensity, which is predicted to result in larger firms (Lucas, 1978). We use the Net Sales to Fixed Assets to control for different financing patterns across firms. Specifically, firms with higher net sales relative to fixed assets might need more short-term financing to support sales. Finally, we use the Return on Assets to explore whether more profitable firms are also larger. The correlation matrix in Table 2 indicates that firms with a higher share of fixed assets are larger in terms of assets in GDP but smaller in terms of U.S. dollars; they are thus smaller in absolute terms, but have a larger market share, compared with firms with less fixed assets.

We use a broad array of economic, social and institutional country-level indicators to assess different theories of firms size. The first group comprises variables that proxy for macroeconomic determinants of firm size. All these variables are available on a yearly basis and come from the World Development Indicators (WDI). The level of Gross Domestic Product (GDP) measures the overall size of the economy, while GDP per capita indicates the income level of countries; both are measured in constant U.S. dollars. As indicated by the data in Tables 1 and 2, there is a wide variation in the income level, ranging from Pakistan (with an average of $\$ 1,563$ over the period $1988-97)$ to the U.S. $(\$ 25,854)$. We use the inflation rate to indicate macroeconomic volatility and uncertainty. Again, there is a wide variation in monetary stability across countries, ranging from an average inflation rate of 1,020 percent in Brazil to less than one percent in Japan. The trade share in GDP - the sum of real exports and imports in real GDP - indicates the degree of openness of economies, while the gross secondary enrolment rate proxies for the level of education in the economy. Our sample includes both very open

\footnotetext{
${ }^{9}$ For a detailed description of the data and its sources, see Appendix.
} 
economies (notably Singapore and Hong Kong with trade being more than three and two times GDP, respectively) and relatively closed economies (Argentina and Brazil with trade being less than $18 \%$ of GDP). The gross secondary enrolment varies from $128 \%$ in the Netherlands to $22 \%$ in Pakistan. ${ }^{10}$

We use two main indicators of financial sector development. We use BANK CREDIT, the claims of deposit money banks on the private sector as share of GDP to indicate the level of financial intermediary development and MARKET CAPITALIZATION, the value of outstanding shares as share of GDP to measure the level of stock market development. Recent research has shown the importance of both financial intermediary and stock market development for economic development. ${ }^{11}$ Access to financial services varies substantially across the countries in our sample. BANK CREDIT constitutes only $8 \%$ of GDP in Peru, while it constitutes $162 \%$ in Switzerland. Similarly, MARKET CAPITALIZATION is only $3 \%$ in Poland, while it is $161 \%$ in South Africa. In our sensitivity analysis we employ several additional financial sector indicators that measure specific aspects of financial sector development. CONCENTRATION is the share of the assets of the three largest banks in total banking sector assets to indicate the degree of bank concentration. Finally PUBLIC BANKS, the percentage of assets of the 10 largest banks owned by the government -as share of total assts of these banks- measures the degree to which commercial banks are owned by the government. Previous research has shown that economies with larger shares of government -owned banks

\footnotetext{
${ }^{10}$ Gross secondary enrollment ratio is the ratio of total enrollment, regardless of age, to the population of the age group that officially corresponds to secondary education. Adult education programs can therefore result in enrolment rates above $100 \%$.

${ }^{11}$ We prefer BANK CREDIT to PRIVATE CREDIT, as used by Levine, Loayza and Beck (2000) and Beck, Levine, and Loayza (2000), since the latter also includes claims on the private sector by nonblank financial intermediaries. These, however, might be in the form of equity holdings, thus be included in MARKET CAPITALIZATION. To avoid double counting, we therefore prefer the more narrow measure of BANK CREDIT.
} 
have lower levels of financial development and experience less economic growth. ${ }^{12}$ All indicators of financial development come from the financial structure database of the World Bank (Beck, Demirgüç-Kunt, and Levine, 2000), with exception of Public, which was collected by La Porta, Lopez-de-Silanes and Shleifer (2001).

We use several indicators of the legal environment to explore whether the legal system of a country has an impact on the size of its firms. Resent research has shown the importance of the rights of outside investors, the efficiency of the legal system in enforcing contracts and the origin of the legal system for financial sector development, firm-growth and economic growth. ${ }^{13}$ LAW\&ORDER is an indicator of the degree to which the citizens of a country are able to use the legal system to mediate conflict and enforce contracts. This index, obtained from the International Country Risk Guide (ICRG), is scored between one and six, with higher values indicating a more efficient legal system. Our sample includes countries with a very high level of contract enforcement (among them Australia, Canada, New Zealand, U.S. and several West European countries) and countries with weak legal enforcement ( Colombia and Peru). CREDITOR-RIGHTS measures the rights of secured creditors in the case of bankruptcy or reorganization. While CREDITOR-RIGHTS indicates the rights of outside investors as detailed in the laws on the books, LAW\&ORDER indicates the efficiency with which these rights and contracts in general are enforced. ${ }^{14}$

\footnotetext{
${ }^{12}$ See La Porta, Lopez-de-Silanes, and Shleifer (2001) and Barth, Caprio and Levine (2001).

${ }^{13}$ La Porta, Lopez-de-Silanes, Shleifer, and Vishny $(1997,1998)$ and Levine, Loayza and Beck (2000) show the importance of the protection of outside investors for financial development. Demirguc-Kunt and Maksimovic (1998) find that firms access more long-term financing in countries with more efficient legal systems. Finally, Porta, Lopez-de-Silanes, Shleifer, and Vishny $(1997,1998)$ and Beck, Demirgüç-Kunt and Levine (2003) show that distinguishing countries by the origin of their legal system can explain variance in financial development across these countries.

${ }^{14}$ We also used an indicator of the legal origin of a country, whether the legal system is based on the Common law or French, German or Scandinavian Civil law system. However, once we controled for the creditor rights and laworder, the origin variable did not develop a significant coefficient in our regressions.
} 
The correlations shown in Table 2 show that firms are larger, as measured by their share of assets in GDP, in countries with smaller GDP, but higher GDP per capita, with a higher trade share, higher secondary enrolment rates, better developed banking sectors and stock markets, more efficient legal system, but less creditor protection. The correlations also reveal some differences between the two measures of firm size - total assets in GDP and assets in constant U.S. dollars. Large firms, as measured in constant U.S. dollars, are larger in countries with a larger GDP, less inflation, and a smaller trade share. These differences can be explained by the fact that Assets in GDP measures the size of the firm relative to its economy, while Assets in constant U.S. dollars measures firm size in absolute terms.

\subsection{Methodology}

We employ two methodologies to explore the determinants of firms' size. Specifically, we use (i) a panel of annual firm-level data, controlling for both firm- and time-specific random effects, and (ii) a cross-section of firm-level data, with data averaged over the sample period and including industry dummies. Our panel regressions take the following form:

$S I Z E_{t, \jmath, t}=\beta_{1}$ IRM $_{\imath, t}+\beta_{2} M A C R O_{\jmath, t}+\beta_{3} F I N A N C E_{\jmath, t}+\beta_{4} L E G A L_{\jmath, t}+v_{\imath}+\tau_{\imath}+\varepsilon_{i, t}$

where SIZE is measured either by total assets in GDP or total assets in constant U.S. dollars, FIRM is a set of firm characteristics, MACRO is an array of macro-economic variables, FINANCE is a vector of indicators of financial development, LEGAL a set of variables measuring the efficiency of the legal system, $v$ the firm-, $\tau$ the time-specific effect, $\varepsilon$ the whitenoise error term and $\mathrm{i}, \mathrm{j}$ and $\mathrm{t}$ indicate firm, country and time period, respectively. 
We will run three regressions, including only one of the three vectors MACRO, FINANCE, and LEGAL at a time, and one regression estimating the complete model. We use random-effects as opposed to fixed-effects, since this allows us to include time-invariant variables, such as creditor rights. The random-effects model is also not as much subject to the effects of measurement errors in the explanatory variables as the fixed-effects model (Moulton, 1987).

As noted above, the legal variables show little if any time-series variation over the sample period. Even the variables in the FINANCE and MACRO vectors show more crosscountry than over-time variance. While the time-series variation in FINANCE and MACRO vectors helps us distinguish the relation of each variable to firm size, there is a risk that using panel techniques might add noise to our coefficient estimates and give the impression that we have more independent observations than we actually have. To guard against this risk we therefore also estimate cross-section regressions where we average the data over the 10-year sample period. Our cross-section regression takes the following form:

$$
S I Z E_{i, j}=\beta_{1} F I R M_{1}+\beta_{2} M A C R O_{j}+\beta_{3} F_{I N A N C E}+\beta_{4} L E G A L_{j}+\zeta_{t}+\varepsilon_{i}
$$

where $\zeta$ is an industry dummy variable for industry $\mathrm{k}$. We control for 20 different industries. ${ }^{15}$ In interpreting estimates of the coefficients of equation (2), we recognize that by eliminating time-series volatility we also increase the risk of not being able to distinguish the contribution of each individual component of FINANCE and LEGAL due to multi-collinearity.

\footnotetext{
${ }^{15}$ See Appendix Table A2 for the list of industries.
} 


\section{The Results}

In Table III we examine the extent to which a country's legal system, financial system, and macro-economic factors explain the sizes of its largest firms. In Columns (1) to (3), we examine each of these factors separately, and in Column (4) we include all of them in a single regression. In Panel A, all regressions are estimated using firm-level pooled data over the 1988-1997 period using firm and year random effects. In Panel B, we adopt a cross-sectional approach in which all variables are averaged over the sample period and the regressions are estimated including industry dummy variables.

As Panel A of Table III shows, a country's legal system, financial system, and macro-economic factors predict the sizes of its largest firms. There is a positive relation between the size of the largest firms and the efficiency of a country's legal system, the level of banking sector development, GDP per capita and the inflation rate. There is a negative relation between the size of the economy, measured by GDP and firm size. The relation between size of the stock market and firm size is weaker: the coefficient of MARKET CAPITALIZATION is positive and significant when only the financial variables are entered in Column (2), but loses significance when all the variables are entered in Column (4). By contrast, Education is significant in column (4), but not significant in column (1), when only the Macro variables are entered. The openness of the economy is not significant in any specification. The results in Panel B, where time-series variation is eliminated are consistent in Columns (1)-(3) when the legal system, financial system, and macro-economic factors are entered in sequence, and somewhat weaker in Column (4), when all the factors are entered together. 
The positive relation of financial development, legal efficiency and firm size, is not only statistically significant, but also of economic significance. One standard deviation increase in BANK CREDIT is associated with an increase of $0.73^{\star} 10^{-6}$ in firm Assets/GDP, which constitutes one sixth of the average firm size in our sample.

Similarly, one standard deviation increase in LAW\&ORDER is associated with an increase of $0.46^{\star} 10^{-6}$ in average firm size relative to GDP, one tenth of the average firm size in our sample.

In our sample, there is also a positive relation between capital intensity (NFATA) and firm size. However, we do not find a significant relation between return on assets and firm size, or between the ratio of sales to net fixed assets and firm size.

Taken together, the coefficients in Table III show that firm size and the development of financial and legal institutions are complements, even when controlling for the general level of income and development. Thus, any advantage internal capital markets might have in allocating resources in countries with weak financial and legal institutions is dominated by the inability of weak institutions to support and monitor large firms.

In Table IV we investigate whether state ownership of banks and the concentration of the banking sector affect firm size. We employ two specifications. In the first specification, we take Column (2) in Table III (where only financial variables are entered) as our baseline model. We add CONCENTRATION and PUBLIC BANKS to the baseline model, one at a time (1-2) and all together (3). In the second specification we take Column (4) in Table III where all the variables are entered together as our baseline model. Again, we add CONCENTRATION and PUBLIC BANKS in the same way to 
this baseline. In Panel A, all regressions are estimated using firm level pooled data over the 1988-1997 period using firm and year random effects. In Panel B, all variables are averaged over the sample period.

Table IV shows that a concentrated banking sector is associated with larger firms. For firms in our sample, there is no evidence that a concentrated banking systems provides a comparative advantage to small size, contrary to the findings of Petersen and Rajan (1995). Instead, at least for the large firms we examine, concentration of the banking system is associated with larger firms, confirming the findings by Cetorelli (2001). The role of public ownership of banks is more ambiguous. Its coefficient is not always significant, but in those cases when it is, it tends to be negative. Thus, state control of the banking system has an effect on firm size similar to that of a reduction in the development of the banking system.

We next examine more closely the effect of the legal system on firm size. Our legal variable, LAW \& ORDER, is an indicator of the degree to which citizens of a country are able to utilize the country's legal system to mediate disputes and enforce contracts. Although Demirguc-Kunt and Maksimovic (1998) find that LAW \& ORDER predicts firms' use of external finance, the measure does not differentiate between legal systems that provide, at least formally, extensive investor protection and those that do not. To address this issue we introduce an index of Creditor Rights, as compiled by LLSV(1998).

In Table $\mathrm{V}$ we examine the relation between firm size and the existence of Creditor Rights and effectiveness of the country's legal system. In the regressions reported in Table V we also interact CREDITOR RIGHTS variable with LAW \& 
ORDER. The interacted variable is thus increasing both on the existence of specific protections, and in the ability of the country's citizens to use the protections that they have been granted.

Table V, Panel A presents the panel results. The coefficients of the interaction between Creditor Rights are consistently negative yet significant only in one specification. In the cross-sectional estimates in Panel $B$, the coefficients are also negative but not significant. Thus, we find weak evidence that firms in countries with strong creditor rights and efficient legal systems are smaller. By contrast, the overall efficiency of the legal system is positively related to firm size as before.

The negative coefficient for creditor rights variable suggests that a high degree of creditor protection may create a comparative advantage for small firms, most likely by making it easier for small firms to obtain external financing. We investigate that possibility next.

To investigate further the relation between firm size, creditor rights and external financing we split the sample into firms that are financing their investment internally and firms that are relying at least partially on external finance. We follow Demirguc-Kunt and Maksimovic (1998) in using the standard "percentage of sales" financial planning model of Higgins (1974) to estimate the growth rates that the firms in our sample can attain using internal finance. ${ }^{16}$ For each firm the growth rate is derived from the financial planning model under the assumption that the firm is self-financing and pays no dividend,

\footnotetext{
${ }^{16}$ The financial planning model makes several implicit assumptions about the relation between the firm's growth rate and its external financing need. First, the ratio of assets used in production to sales is assumed to be constant. Second, the firm's profit rate per unit of sales is constant. This assumption was examined in Demirguc-Kunt and Maksimovic (1998). The results in that paper were not sensitive to different assumptions about the rate of return on marginal sales. Third, we assume that the economic depreciation of existing assets equals that reported in the financial statements.
} 
and is given by for time $t$ by $R O A_{\downarrow}\left(\left(1-R O A_{v}\right)\right.$, where $R O A_{t}$ is the firm's return on assets. For each firm in each year we define a variable EXFIN, which is the excess firm growth given by the difference between their growth and our estimate of the maximum rate attainable if the firm is entirely self-financing. Thus, EXFIN is an indicator of dependence of external financing.

In Table VI, we interact LAW \&ORDER and CREDITOR RIGHTS and our two financial variables BANK CREDIT and MARKET CAPITALIZATION with EXFIN and include the interacted variables to our specification. As before, an efficient legal system is positively related to firm size and creditor rights are negatively related to firm size. However, these relations are stronger for externally financed firms. The estimates show that as creditor protections improve, the mean size of firms that obtain external financing declines both absolutely and relative to firms that do not obtain external financing. The pattern of size declines suggests that large firms lose comparative advantage in obtaining external financing.

We next check whether our results are sensitive to our definition of firm size. By normalizing the firm's assets by its country's GDP, our definition of firm size provides a rough measure of the extent to which the country's economic activity is controlled by the firm. This empirical definition thus captures the extent to which activities within the country are controlled within the boundaries of the firms in our sample. An implication of this definition is that a large firm in a small poor country might produce the same cash flows as a small firm in a large rich country.

To explore the implications of our normalization, Table VII replicates Table III, using the U.S. dollar value of the firm's total assets as our measure of size. The 
coefficient estimates are consistent with the earlier reported results. Firms are larger in high-income countries with large banking systems, efficient legal systems. Fixed assets are associated with large firms. Large economies have larger firms, as measured in U.S. dollars, while we found them to have smaller firms relative to GDP (Table III).

\section{Correlusion}

In this paper we examine the relation between the development of a country's financial and legal institutions and the size of the largest private firms in the country. Both firms' internal capital markets and a country's financial institutions perform similar tasks in funding and monitoring investment projects. Thus, we expect that in countries with underdeveloped institutions, firms' internal capital markets substitute for external providers of capital. If this effect is significant, then we expect to observe that firms are larger in such countries.

However, large firms concentrate financial power in the hands of corporate insiders who have an incentive to misappropriate the firm's assets. A sophisticated financial sector and an efficient legal system might be necessary to control such misappropriation. Hence, large firms and strong institutions might be complements.

We find empirically that firms are larger in countries with more developed, concentrated banking sectors and efficient legal systems. These relations are stronger for firms that are externally financed. Firm size is not as strongly associated with a large stock market. These effects persist when we control for a country's general level of economic development and size. Firm size and the effectiveness of a county's institutions are complements. We do, however, find a negative relation between strong creditor rights 
and firm size particularly for externally financed firms. Thus, strong creditor rights might allow small firms to borrow directly from banks, reducing the role of large internal capital markets.

Overall, our results do not support the view that large firms with internal markets and hierarchies can compensate for the underdevelopment of financial and legal institutions in a country. Rather, well developed institutions are a pre-requisite for the development of large corporations. This finding holds for both financial and legal institutions, with the exception that internal capital markets may substitute for the absence of creditor protections. However, it is likely that agency costs at the firm level dissipate the advantages of internalizing the allocation of capital in countries with underdeveloped institutions. $^{17}$

A limitation of our analysis is that it focuses on large firms. While the tradeoffs we examine are likely to be most relevant to large firms, our findings do not address the relation between financial institutions and the size distribution of small firms.

\footnotetext{
${ }^{17}$ As recent financial scandals in U.S. indicate, the issue of control of agency costs of large firms is also important in countries at the highest levels of institutional development.
} 


\section{RERENCES}

Ball, R., Kothari, S.P. and Robin, A., 2000. The effect of international institutional factors on properties of accounting earnings. Journal of Accounting and Economics 29, 1-51.

Barth, J.R.; Caprio, G. Jr.; Levine, R., 2001, "The Regulation and Supervision of Banks around the World. A New Database. In: Litan, R.E.; Herring, R. (Eds.), Integrating Emerging Market Countries into the Global Financial System. Brookings Institution Press, Washington, D.C.

Beck, Thorsten; Levine, Ross; Loayza, Norman, 2000, "Finance and the Sources of Growth," Journal of Financial Economics, 58(1).

Beck, Thorsten; Demirguc-Kunt, Asli; Levine, Ross, 2000, "A New database on the Structure and Development of the Financial Sector" The World Bank Economic Review (14), 597 605.

Beck, Thorsten; Demirguc-Kunt, Asli; Levine, Ross, 2003, “Law, Endowments, and Finance", Journal of Financial Economics, forthcoming.

Beck, Thorsten; Demirguc-Kunt, Asli; Maksimovic, Vojislav, 2002, Financial and Legal Constraints to Firm Growth: Does Size Matter?, World Bank Mimeo.

Beck, Thorsten; Demirguc-Kunt, Asli; Maksimovic, Vojislav, 2003, Bank Competition, Financing Obstacles and Access to Credit, World Bank Mimeo.

Berger and Ofek, 1995, Diversification's effect on firm value, Journal of Financial Economics 37, 39-66

Carlin W. and Colin Mayer, 1999, Finance, Investment and Growth, Unpublished Working Paper, University College, London.

Cetorelli and Peretto, 2000, Oligopoly banking and capital accumulation, Working Paper, Federal Reserve Bank of Chicago

Coase, R. H, 1937, The Nature of the Firm, Economica 386-405.

Comment and Jarrell, 1995, Corporate Focus and Stock Returns, Journal of Financial Economics 37, 67-87

Demirgüç-Kunt, Asli and Vojislav Maksimovic, 1998, Law, Finance, and Firm Growth, Journal of Finance 53, 2107-2137.

Demirgüç-Kunt, Asli and Vojislav Maksimovic, 1999, Institutions, Financial Markets And Firm Debt Maturity, Journal of Financial Economics. 
Demirgüç-Kunt, Asli and Vojislav Maksimovic, 2001, Firms as Financial Intermediaries: Evidence from Trade Credit Data, World Bank Working Paper.

Dinc, 2000, Bank Reputation, Bank Commitment and the Effects of Competition in Credit Markets, Review of Financial Studies 13, 781-812

Fazzari, Steven M., R. Glenn Hubbard, and Bruce C. Petersen, 1988, Financing constraints and corporate investment, Brookings Papers on Economic Activity 19, 141-195.

Fluck, Z, 1999, "The Dynamics of the Management-Shareholder Conflict", Review of Financial Studies, 12 (Summer), 379-404.

Fluck, Z. and A. Lynch, 1999, "Why Firms Merge and Then Divest: A Theory of Financial Synergy", The Journal of Business, 72 (July), 319-346.

Harvey and Rouwenhurst, 2002, Emerging Markets Finance, Duke University Working Paper.

Hung, Mingyi, 2001, Accounting standards and value relevance of financial statements: An international analysis, Journal of Accounting and Economics 30, 401-420.

Johnson, Simon; Daniel Kaufmann, John McMillan, and Christopher Woodruff, 2000, "Why do firms hide? Bribes and unofficial activity after communism," Journal of Public Economics, 76, 495-520.

King, Robert G. and Levine, Ross,1993, "Finance and Growth: Schumpeter Might Be Right", Quarterly Journal of Economics, 108, 717-38.

Kumar, Rajan and Zingales, 2001, What Determines Firm Size, NBER Working Paper $\# 7208$.

Lang and Stulz, 1994, Tobin's $q$ Corporate Diversification and Firm Performance, Journal of Political Economy 102(6), 1248-1280

La Porta, Rafael; Lopez-de-Silanes, Florencio, and Shleifer, Andrei; 1999, Corporate Ownership Around the World, Journal of Finance 53.

La Porta, Rafael; Lopez-de-Silanes, Florencio; Shleifer, Andrei; and Vishny, Robert W. 1998, Law and Finance, Journal of Political Economy 106, 1113-1155.

La Porta, Rafael; Lopez-de-Silanes, Florencio; Shleifer, Andrei; and Vishny, Robert W. 1997, Legal Determinants of External Finance, Journal of Finance 52, 11311150 . 
La Porta, Rafael; Lopez-de-Silanes, Florencio; Shleifer, Andrei; 2002 Government Ownership of Banks, Journal of Finance 57(1).

Levine, Ross and Zervos, Sara, 1998, "Stock Markets, Banks, and Economic Growth," American Economic Review, 88(3), 537-558.

Love, Inessa, 2001, "Financial Development and Financing Constraints: International Evidence from the Structural Investment Model," World Bank Working Paper, No. 2694.

Lucas, Robert E.,1978, On the size and distribution of business firms, Bell Journal of Economics 9(2), 508-523.

Maksimovic and Phillips, 2002, Do Conglomerate Firms Allocate Resources Inefficiently Across Industries? Theory and Evidence, Journal of Finance, 721-767.

Marquez, 2000, Corporate Reorganizations and Non-cash Auctions, The Journal of Finance, 55(4), 1850-1854.

Mauro, Paul, 1996, "The Effects of Corruption on Growth, Investment and Government Expenditure," IMF Working Paper 96/98.

Modigliani, Franco and Enrico Perotti, 1998, Security versus bank finance: the importance of a proper enforcement of legal rules, Unpublished MIT working paper.

Moulton, 1987, Diagnostic for group effects in regression analysis, Journal of Business and Economic Statistics 5, 275-282.

Petersen and Rajan, 1995, The Effect of Credit Market Competition on Lending Relationships, Quarterly Journal of Economics 110(2), 407-443

Pistor, K., 1999. Law as a determinant of equity market development. Unpublished working paper, Harvard University, Cambridge, MA.

Rajan, Raghuram and Luigi Zingales, 1998, Financial dependence and growth, American Economic Review 88, 559-587.

Rajan, Raghuram and Luigi Zingales, L., 1999, The politics of financial development. Unpublished working paper, University of Chicago, Chicago, IL.

Rajan, Servaes and Zingales, 2000, The Costs of Diversity: The diversification discount and inefficient investment, Journal of Finance, 55(1), 35-80.

Schiffer, Mirjam and Beatrice Weder, 2001, Firm Size and the Business Environment: Worldwide Survey Results, IFC discussion paper number 43. 
Shleifer, A. and R. Vishny, 1993, Corruption, Quarterly Journal of Economics, 108 (3), 995-1025.

Stein, 1997, Internal Capital Markets and the Competition for Corporate Resources, Journal of Finance 52, 111-133.

Stein, 2002, Information Production and Capital Allocation: Decentralized versus Hierarchical Firms, Journal of Finance 57(5).

Stulz, Rene and Williamson, Rohan, 2001, Culture, Openness, and Finance, University of Ohio mimeo.

Wurgler, J., 2000, Financial markets and the allocation of capital, Journal of Financial Economics 58, 187-214.

You, Jong-Il, 1995, Small firms in economic theory, Cambridge Journal of Economics $19,441-462$. 


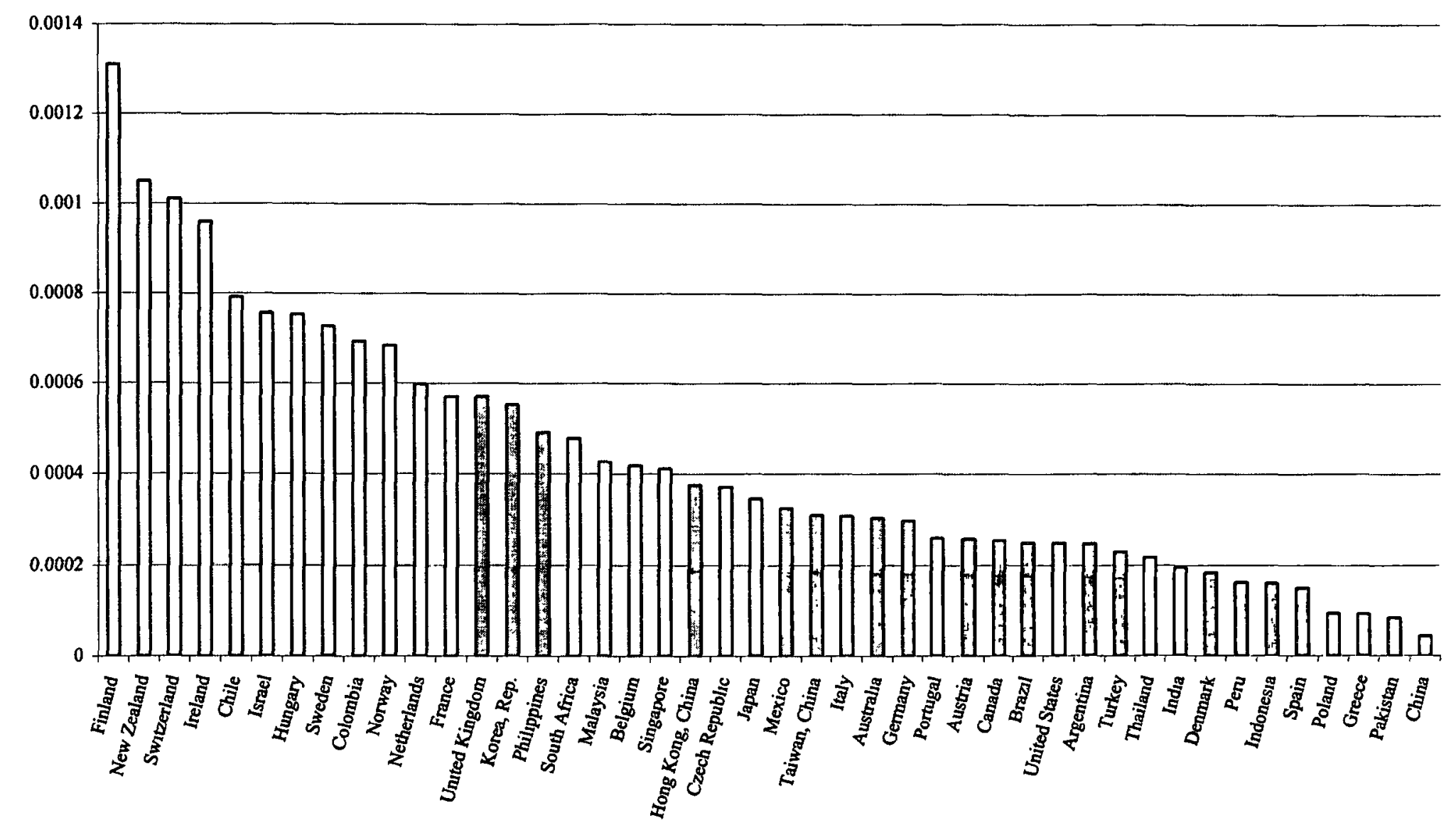

Figure 1. Assets/GDP is given by total assets of the largest 100 firms in manufacturing divided by GDP. The figure presents the average Assets/GDP values for firms in each country for 1988-1997. The countries are in descending order. 


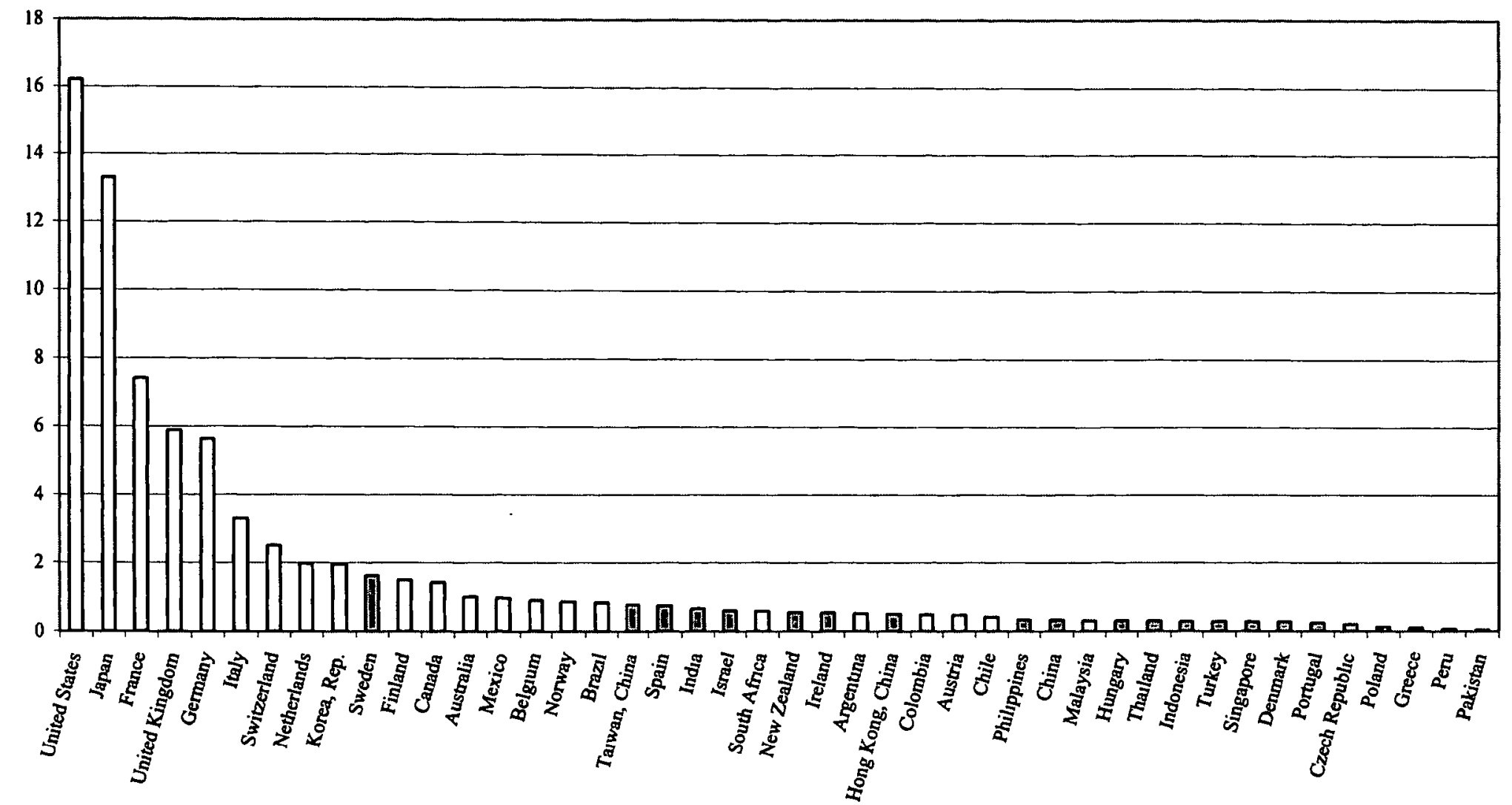

Figure 2. Assets is given by total assets of the largest 100 firms in manufacturing in millions of US dollars.. The figure presents the average assets for firms in each country for 1988-1997. The countries are in descending order. 
Table I

Economic and Institutional Indicators

GDP/CAP is the real GDP per capita in USS. INFLATION is the log difference of the Consumer Price Index. OPENNESS is given by imports plus exports divided by GDP EDUCATION is gross enrolment in secondary schools. BANK CREDIT is bank credit extended to the private sector divided by GDP. MARKET CAPITALIZATION is stock market capitalization divided by GDP. LAW \& ORDER, scored 1 to 6 , is an indicator of the degree to which citizens of a country are able to utilize the existing legal system to mediate disputes and enforce contracts. Values are 1988-97 averages.

\begin{tabular}{|c|c|c|c|c|c|c|c|}
\hline & $\begin{array}{c}\text { GDP/CAP } \\
\text { (US \$) }\end{array}$ & INFLATION & OPENNESS & EDUCATION & $\begin{array}{c}\text { BANK } \\
\text { CREDIT }\end{array}$ & $\begin{array}{c}\text { MARKET } \\
\text { CAPITALIZAT } \\
\text { ION }\end{array}$ & $\begin{array}{l}\text { LAW \& } \\
\text { ORDER }\end{array}$ \\
\hline Argentina & 9972 & 567 & 17.78 & 72.11 & 0.15 & 0.09 & 39 \\
\hline Australia & 19353 & 0.03 & 36.75 & 111.80 & 0.65 & 0.66 & 6 \\
\hline Austria & 20737 & 003 & 77.49 & 104.29 & 0.91 & 0.12 & 6 \\
\hline Belgium & 21255 & 0.03 & 137.08 & 123.99 & 051 & 036 & 5.9 \\
\hline Brazil & 6182 & 1020 & 17.04 & 44.80 & 0.23 & 0.17 & 36 \\
\hline Canada & 21677 & 0.02 & 61.82 & 102.53 & 0.54 & 0.57 & 6 \\
\hline Chile & 6418 & 013 & 60.97 & 7163 & 0.44 & 0.73 & 44 \\
\hline China & 2064 & 0.10 & 36.96 & 56.98 & 0.85 & 0.08 & 41 \\
\hline Colombia & 5340 & 0.25 & 34.48 & 55.58 & 0.15 & 011 & 1.4 \\
\hline Czech Republic & 12016 & 016 & 106.42 & 92.51 & 0.56 & 0.27 & 58 \\
\hline Denmark & 21538 & 0.03 & 6645 & 11300 & 0.40 & 0.33 & 6 \\
\hline Finland & 18291 & 0.03 & 5705 & 116.22 & 0.77 & 029 & 6 \\
\hline France & 19431 & 002 & 4331 & 103.79 & 088 & 0.32 & 5.5 \\
\hline Germany & 21077 & 0.03 & 4945 & 103.19 & 0.92 & 0.24 & 6 \\
\hline Greece & 12397 & 0.13 & 44.74 & 94.16 & 018 & 013 & 46 \\
\hline Hong Kong & 19646 & 0.08 & 273.24 & 79.15 & 1.42 & 1.79 & 4.9 \\
\hline Hungary & 9319 & 0.23 & 69.99 & 84.58 & 0.36 & 004 & 53 \\
\hline India & 1626 & 009 & 2092 & 46.22 & 0.25 & 024 & 2.9 \\
\hline Indonesia & 2434 & 0.09 & 5070 & 47.22 & 0.42 & 0.15 & 3.5 \\
\hline Ireland & 15141 & 003 & 124.61 & 108.29 & 0.29 & 0.26 & 52 \\
\hline Israel & 15393 & 0.14 & 78.08 & 86.26 & 0.58 & 0.30 & 3.7 \\
\hline Italy & 19058 & 0.05 & 42.27 & 87.36 & 0.52 & 0.17 & 5.2 \\
\hline Japan & 21928 & 001 & 18.52 & 98.04 & 1.16 & 0.89 & 5.6 \\
\hline Korea & 11306 & 007 & 6110 & 9424 & 0.51 & 0.39 & 3.8 \\
\hline Malaysia & 6191 & 0.04 & 161.36 & 58.46 & 0.72 & 1.75 & 4 \\
\hline Mexico & 6964 & 0.31 & 4401 & 56.61 & 0.19 & 0.27 & 3 \\
\hline Netherlands & 19273 & 0.02 & 11040 & 127.51 & 088 & 0.65 & 6 \\
\hline New Zealand & 15841 & 0.03 & 5694 & 99.82 & 069 & 0.46 & 6 \\
\hline Norway & 22655 & 003 & 7156 & 110.41 & 0.58 & 0.24 & 6 \\
\hline Pakistan & 1563 & 011 & 38.41 & 21.70 & 0.23 & 014 & 2.3 \\
\hline Peru & 3965 & 1069 & 30.28 & 68.01 & 008 & 0.11 & 2 \\
\hline Philippines & 3463 & 009 & 72.39 & 75.65 & 0.26 & 0.44 & 2.5 \\
\hline Poland & 6384 & 0.31 & 45.89 & 88.49 & 008 & 0.03 & 5 \\
\hline Portugal & 12523 & 008 & 6726 & 8454 & 053 & 0.14 & 5.2 \\
\hline Singapore & 15987 & 0.03 & 365.24 & 69.94 & 0.81 & 1.27 & 5.4 \\
\hline S.Africa & 8435 & 0.13 & 44.14 & 80.49 & 0.58 & 1.61 & 2.6 \\
\hline Spain & 14157 & 0.05 & 40.63 & 111.60 & 0.68 & 0.29 & 5.1 \\
\hline Sweden & 19114 & 0.04 & 64.89 & 113.30 & 047 & 0.60 & 6 \\
\hline Switzerland & 24801 & 0.03 & 69.78 & 99.76 & 162 & 094 & 6 \\
\hline Taiwan & 14268 & 0.03 & 9059 & . & 1.16 & 0.84 & 4.9 \\
\hline Thailand & 4981 & 0.05 & 80.33 & 41.69 & 0.72 & 0.49 & 45 \\
\hline Turkey & 5434 & 0.75 & 38.62 & 51.61 & 013 & 012 & 3.5 \\
\hline U K. & 18178 & 0.05 & 52.54 & 11024 & 1.10 & 1.08 & 5.4 \\
\hline U S. & 25854 & 0.03 & 21.67 & 9594 & 066 & 0.75 & 6 \\
\hline
\end{tabular}


Table II

\section{Summary Statistics and Correlations}

Summary statistics and correlations are presented in Panel $A$ and $B$ of the table, respectively. $N$ refers to firm level observations for 44 countries over the 1988-1997 period. The variables are defined as follows ASSETS/GDP is given by total assets of the firm divided by GDP. Assets (\$) is total firm assets in billions of US \$. NFATA is the net fixed assets divided by total assets. NSNFA is the net sales divided by net fixed assets. ROA is return on assets. GDP is given in billions of U.S. dollars. GDP/CAP is real GDP per capita in thousands of US\$. INFLATION is the log difference of the Consumer Price Indicator. OPENNESS is given hy imports plus exports divided by GDP. EDUCATION is gross enrolment in secondary schools BANK CREDIT is bank credit extended to the private sector divided by GDP MARKET CAPITALLZATION is stock market capitalization divided by GDP. LAW \& ORDER, scored 1 to 6 , is an indicator of the degree to which citizens of a country are able to utilize the existing legal system to mediate disputes and enforce contracts. CREDITOR RIGHTS, scored 0 to 4 , is an index aggregating different creditor rights Detailed variable defintions and sources are given in the appendix.

\section{Panel A: Summary Statistics}

\begin{tabular}{|c|c|c|c|c|c|}
\hline & $\bar{N}$ & Mean & Std Dev & Minimum & Maximum \\
\hline ASSETS/GDP & 19912 & $4.65 \times 10^{-6}$ & $118 \times 10^{-5}$ & 0.00000 & 0.00022 \\
\hline ASSETS (\$) & 20185 & 0003 & 0010 & 0000 & 0275 \\
\hline NFATA & 19724 & 0370 & 0.180 & 0000 & 1.000 \\
\hline NSNFA & 19636 & 4491 & 17806 & 0.000 & 941.548 \\
\hline ROA & 19250 & 0042 & 0207 & -25.890 & 1.932 \\
\hline GDP (\$) & 29622 & 699 & 1350 & 124 & 8240 \\
\hline GDP/CAP & 29564 & 14.374 & 7.636 & 1293 & 30013 \\
\hline INFLATION & 29463 & 0505 & 3.165 & .0015 & 68370 \\
\hline OPENNESS & 29599 & 74282 & 68977 & 13.244 & 406750 \\
\hline EDUCATION & 24845 & 86534 & 28.137 & 18900 & 152.700 \\
\hline BANK CREDIT & 29097 & 0670 & 0365 & 0016 & 1676 \\
\hline MARKET CAPITALIZATION & 28743 & 0583 & 0.543 & 0002 & 2881 \\
\hline LAW \& ORDER & 29095 & 4841 & 1363 & 1 & 6 \\
\hline CREDITOR RIGHTS & 28540 & 2255 & 1258 & 0 & 4 \\
\hline
\end{tabular}


Pamel B: Correlatiom Matrix of Variables

\begin{tabular}{|c|c|c|c|c|c|c|c|c|c|c|c|c|c|}
\hline & $\begin{array}{c}\text { ASSETS/ } \\
\text { GDP }\end{array}$ & $\begin{array}{c}\text { ASSETS } \\
(\$)\end{array}$ & NFATA & NSNFA & ROA & GDP & $\begin{array}{l}\text { GDP/ } \\
\text { CAP }\end{array}$ & NNFL. & OPENNESS & EDUCATION & $\begin{array}{c}\text { BANK } \\
\text { CREDIT }\end{array}$ & $\begin{array}{c}\text { MARKET } \\
\text { CAPITALIZA } \\
\text { TION } \\
\end{array}$ & $\begin{array}{l}\text { LAW } \\
\text { AND } \\
\text { ORDER } \\
\end{array}$ \\
\hline ASSETS (\$) & $0.42^{\circ}$ & & & & & & & & & & & & \\
\hline NFATA & $0.05^{2}$ & $-0.07^{\circ}$ & & & & & & & & & & & \\
\hline NSNFA & -0.01 & -0.01 & $-0.05^{\circ}$ & 1.00 & & & & & & & & & \\
\hline ROA & 0.00 & $-0.01^{c}$ & $-0.02^{\circ}$ & -0.02 & 1.00 & & & & & & & & \\
\hline GDP & $-0.05^{\circ}$ & $0.43^{\circ}$ & $-0.08^{\circ}$ & -0.01 & $-0.01^{c}$ & & & & & & & & \\
\hline GDP/CAP & $0.07^{\circ}$ & $0.23^{\circ}$ & $-0.12^{2}$ & $0.01^{\mathrm{s}}$ & $-0.04^{2}$ & $0.42^{\circ}$ & & & & & & & \\
\hline INFL. & -0.01 & $-0.03^{\circ}$ & $0.10^{\circ}$ & 0.00 & -0.01 & $-0.04^{\circ}$ & $-0.17^{\circ}$ & & & & & & \\
\hline OPENNESS & $0.06^{\mathrm{n}}$ & $-0.14^{\mathrm{a}}$ & $0.01^{c}$ & 0.01 & $0.02^{\circ}$ & $-0.27^{\circ}$ & $0.12^{\circ}$ & $-0.11^{\circ}$ & & & & & \\
\hline EDUCAT. & $0.07^{\circ}$ & $0.10^{\circ}$ & $-0.16^{\circ}$ & $0.03^{\circ}$ & $-0.06^{-}$ & $0.17^{\circ}$ & $080^{\circ}$ & $-0.22^{\circ}$ & $-0.02^{\mathrm{a}}$ & - & & & \\
\hline $\begin{array}{l}\text { BANK } \\
\text { CREDIT }\end{array}$ & $0.08^{\circ}$ & $0.14^{\circ}$ & $-0.11^{\circ}$ & 0.00 & -0.01 & $0.18^{\circ}$ & $0.53^{\circ}$ & $-0.20^{\circ}$ & $0.28^{\mathrm{a}}$ & $0.35^{\circ}$ & & & \\
\hline $\begin{array}{l}\text { MARKET } \\
\text { CAPITALIZ } \\
\text { ATION }\end{array}$ & $005^{\circ}$ & $0.04^{\circ}$ & $0.05^{\circ}$ & $-0.01^{c}$ & $0.04^{2}$ & $0.05^{\circ}$ & $0.21^{\circ}$ & $-0.12^{\mathrm{a}}$ & $0.55^{\circ}$ & $0.04^{\circ}$ & $0.51^{\circ}$ & & \\
\hline LAW ORD & $0.05^{\circ}$ & $0.13^{a}$ & $-0.15^{\circ}$ & $0.01^{b}$ & $-0.03^{\circ}$ & $0.25^{\circ}$ & $0.77^{a}$ & $-0.17^{\circ}$ & $0.13^{\circ}$ & $0.68^{\circ}$ & $0.45^{\mathrm{a}}$ & $0.14^{\circ}$ & \\
\hline $\begin{array}{l}\text { CREDITOR } \\
\text { RIGHTS }\end{array}$ & $-004^{a}$ & $-0.10^{n}$ & $0.03^{\circ}$ & 0.00 & $0.02^{\mathrm{s}}$ & $-0.21^{\mathrm{a}}$ & $-0.28^{\circ}$ & $-0.16^{\circ}$ & $041^{n}$ & $-0.27^{\circ}$ & $0.09^{\circ}$ & $0.32^{\circ}$ & $-0.20^{\circ}$ \\
\hline
\end{tabular}

$\overline{a, b}$ and ${ }^{c}$ stand for significance levels at 1,5 and 10 percent, respectively. 


\section{Table III}

\section{Determinants of Firm Size}

The regression equation estimated is: SIZE $=\forall+\exists_{1}$ NFATA $+\exists_{2}$ NSNFA $+\exists_{3}$ ROA $+\exists_{4}$ GDP $+\exists_{9}$ GDP/CAP $+\exists_{6}$ INFLATION $+\exists_{7}$ OPENNESS $+\exists_{8}$ EDUCATION $+\exists_{9}$ BANK CREDIT $+\exists_{10}$ MARKET CAPITALIZATION $+\exists_{11}$ LAW \& ORDER,+ . Dependent variable, SIZE, is given by total assets of the firm divided by GDP. NFATA is the net fixed assets divided by total assets. NSNFA is the net sales divided by net fixed assets. ROA is retum on assets. GDP is given in billions of U.S. dollars. GDP/CAP is real GDP per capita in US\$. INFLATION is the log difference of the Consumer Price Indicator. OPENNESS is given by imports plus exports divided by GDP. EDUCATION is gross enrolment in secondary schools. BANK CREDIT is bank credit extended to the private sector divided by GDP. MARKET CAPITALIZATION is stock market capitalization divided by GDP. LAW \& ORDER, scored 1 to 6, is an indicator of the degree to which citizens of a country are able to utilize the existing legal system to mediate disputes and enforce contracts. Specifications (1-3) enter groups of variables separately. Specification (4) is the full model. In Panel A, all regressions are estimated using firm level pooled data over the 1988-1997 period using firm and year random effects. In Panel B, all variables are averaged over the sample period and regressions are estimated including industry dummy variables. Standard errors are given in parentheses. In all specifications coefficients are multiplied by $10^{6}$. Detailed variable definitions and sources are given in the appendix.

Panel A: Panel Results

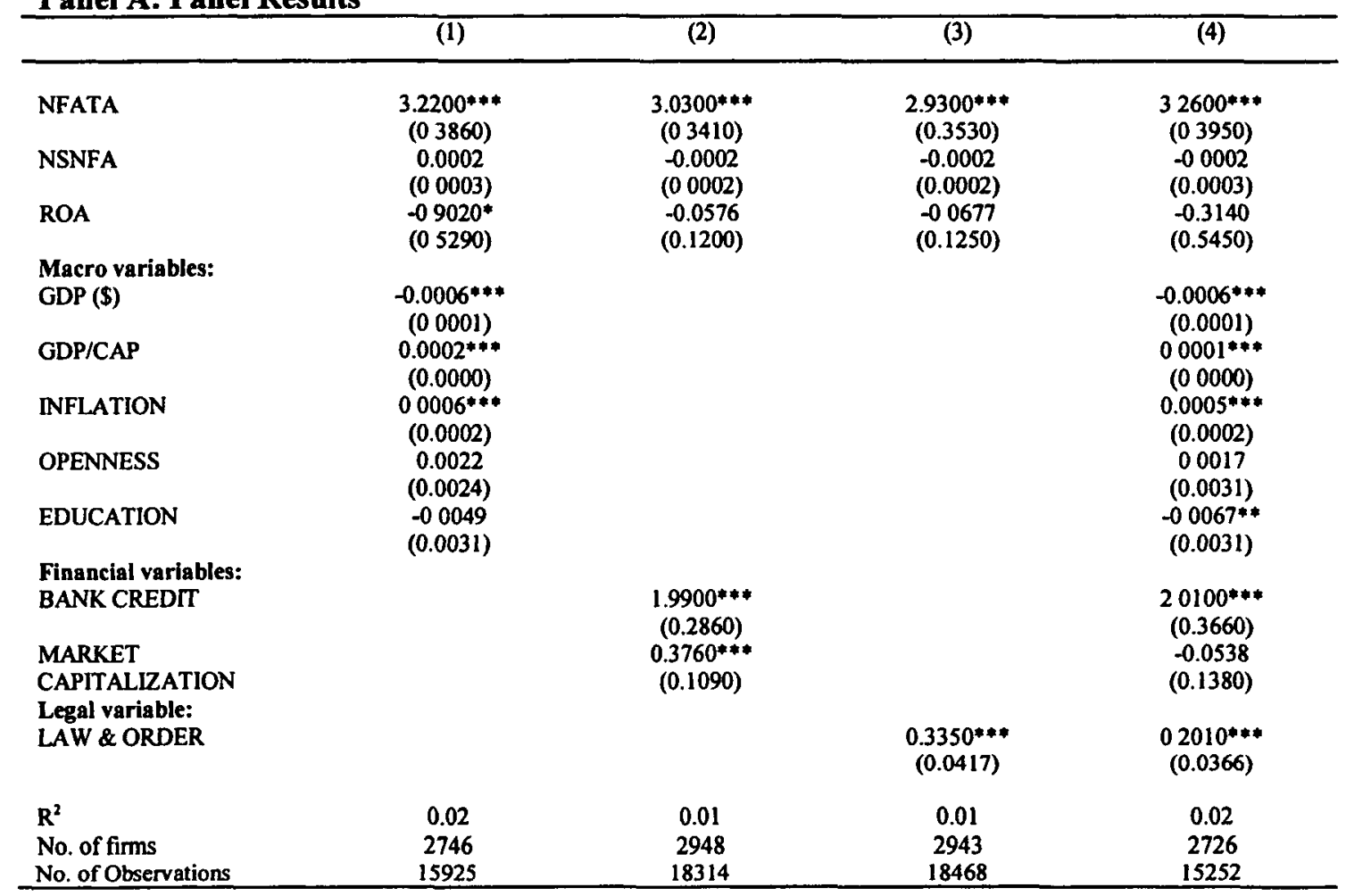

*,** and *** indicate significance levels of 10,5 and 1 percent respectively. 
Panel B: Cross-Section Resuits

\begin{tabular}{|c|c|c|c|c|}
\hline & (1) & (2) & (3) & (4) \\
\hline NFATA & $2.8600^{\circ}$ & 1.7000 & $2.2500^{\circ}$ & $2.7200^{\circ}$ \\
\hline NSNFA & $\begin{array}{c}-0.0004 \\
(0.0006)\end{array}$ & $\begin{array}{l}-0.0002 \\
(0.0006)\end{array}$ & $\begin{array}{l}-0.0003 \\
(0.0006)\end{array}$ & $\begin{array}{l}-0.0003 \\
(0.0006)\end{array}$ \\
\hline ROA & $\begin{array}{c}0.3370 \\
(2.3600)\end{array}$ & $\begin{array}{l}-0.1620 \\
(2.3000)\end{array}$ & $\begin{array}{c}0.4790 \\
(2.2900)\end{array}$ & $\begin{array}{c}0.0254 \\
(2.3600)\end{array}$ \\
\hline $\begin{array}{l}\text { Macro variables: } \\
\text { GDP (\$) }\end{array}$ & $\begin{array}{c}-0.0008^{\circ} \\
(00002)\end{array}$ & & & $\begin{array}{c}-0.0009000 \\
(0.0002)\end{array}$ \\
\hline GDP/CAP & $\begin{array}{l}0.0001 \\
(0.0001)\end{array}$ & & & $\begin{array}{l}-0.0001 \\
(0.0001)\end{array}$ \\
\hline INFLATION & $\begin{array}{c}-0.0005 \\
(0.0010)\end{array}$ & & & $\begin{array}{l}-0.0016 \\
(0.0010)\end{array}$ \\
\hline OPENNESS & $\begin{array}{c}0.0010 \\
(0.0033)\end{array}$ & & & $\begin{array}{c}-0.0041 \\
(0.0042)\end{array}$ \\
\hline EDUCATION & $\begin{array}{c}0.0283 \\
(0.0153)\end{array}$ & & & $\begin{array}{l}0.0411^{60} \\
(0.0163)\end{array}$ \\
\hline $\begin{array}{l}\text { Financial variables: } \\
\text { BANK CREDTT }\end{array}$ & & $\begin{array}{c}2.5700^{\circ 000} \\
(0.6450)\end{array}$ & & $\begin{array}{c}2.1100^{0} \\
(0.8270)\end{array}$ \\
\hline $\begin{array}{l}\text { MARKET } \\
\text { CAPITALIZATION }\end{array}$ & & $\begin{array}{c}0.1910 \\
(0.4840)\end{array}$ & & $\begin{array}{c}0.7270 \\
(0.6490)\end{array}$ \\
\hline $\begin{array}{l}\text { Legal variable: } \\
\text { LAW \& ORDER }\end{array}$ & & & $\begin{array}{c}0.8020^{\circ} \\
(01660)\end{array}$ & $\begin{array}{l}-0.3600 \\
(0.3790)\end{array}$ \\
\hline $\begin{array}{l}\mathrm{R}^{2} \\
\text { No. of firms } \\
\text { No. of Observations }\end{array}$ & $\begin{array}{r}0.06 \\
2861 \\
2861\end{array}$ & $\begin{array}{l}0.05 \\
2961 \\
2961\end{array}$ & $\begin{array}{l}0.05 \\
2961 \\
2961 \\
\end{array}$ & $\begin{array}{l}0.07 \\
2861 \\
2861\end{array}$ \\
\hline
\end{tabular}




\section{Table IV}

\section{Determinants of Firm Size - Additional Financial Variables}

The regression estimated is SIZE $=\forall+\exists_{1}$ NFATA $+\exists_{2}$ NSNFA $+\exists_{3}$ ROA $+\exists_{4}$ GDP $+\exists_{9}$ GDP/CAP $+\exists_{6}$ INFLATION $+\exists_{7}$ OPENNESS $+\exists_{8}$ EDUCATION $+\exists_{9}$ BANK CREDIT $+\exists_{10}$ MARKET CAPITALIZATION+ $\exists_{11}$ LAW \& ORDER $+\exists_{12}$ CONCENTRATION $+\exists_{13}$ PUBLIC BANKS $+\ldots$ Specification (a) corresponds to specification (2) in Table lil where only financial variables are entered. To this baseline CONCENTRATION and PUBLIC BANKS are added one at a time (1-2) and all together (3). Specification (b) corresponds to specification (4) in Table III and estimates the full model. Again, the additional variables are added in the same way to this baseline. CONCENTRATION is the share of the assets of 3 largest banks in total banking assets. It is calculated from individual banking data by averaging over all the banks in the country and are available for the 1990-97 period. PUBLIC BANKS is percentage of assets of the 10 largest banks in each country owned by the government as a share of total assets of these banks in 1995. In Panel A, all regressions are estimated using firm level pooled data over the 1988-1997 period using firm and year random effects. In Panel B, all variables are averaged over the sample period and regressions are estimated including industry dummy variables. Standard errors are given in parentheses. In all specifications coefficients are multiplied by $10^{6}$. Detailed variable definitions and sources are given in the appendix.

Panel A: Panel Results

\begin{tabular}{|c|c|c|c|c|c|c|}
\hline & \multicolumn{2}{|c|}{ (1) } & \multicolumn{2}{|c|}{ (4) } & \multicolumn{2}{|c|}{ (5) } \\
\hline & $\mathbf{a}$ & b & $\mathbf{a}$ & $\mathbf{b}$ & $\mathbf{a}$ & b \\
\hline BANK CREDIT & $\begin{array}{l}2.5600^{*} * \\
(0.3090)\end{array}$ & $\begin{array}{l}2.4400^{* * *} \\
(0.3900)\end{array}$ & $\begin{array}{l}2.0900^{* * * *} \\
(02930)\end{array}$ & $\begin{array}{l}2.2600^{* * *} \\
(0.3750)\end{array}$ & $\begin{array}{l}2.5700^{* * 4} \\
(03200)\end{array}$ & $\begin{array}{l}2.5500^{* * *} \\
(0.4060)\end{array}$ \\
\hline MARKET & $0.4770^{* * *}$ & -00709 & $0.3640^{* * 4}$ & 00085 & $0.4540 * *$ & -0.0348 \\
\hline CAPITALIZATION & $(0.1290)$ & $\left(\begin{array}{lll}0 & 1760\end{array}\right)$ & $(0.1130)$ & $(0.1430)$ & $(0.1370)$ & $(0.1850)$ \\
\hline CONCENTRATION & $\begin{array}{l}1.6800^{* * *} \\
(0.2950)\end{array}$ & $\begin{array}{l}1.3000^{* *} \\
(0.3530)\end{array}$ & & & $\begin{array}{l}1.6700^{* * *} \\
(0.3080)\end{array}$ & $\begin{array}{l}1.2600 * * * \\
(0.3660)\end{array}$ \\
\hline PUBLIC BANKS & & & $\begin{array}{l}-0.0160 * * \\
(00071)\end{array}$ & $\begin{array}{l}-0.0088 \\
(00088)\end{array}$ & $\begin{array}{l}-0.0157^{*} \\
(0.0073)\end{array}$ & $\begin{array}{l}-0.0115 \\
(00093)\end{array}$ \\
\hline $\mathbf{R}^{2}$ & 0.02 & 0.02 & 0.0097 & 0.02 & 0.02 & 0.02 \\
\hline No of Firms & 2903 & 2683 & 2729 & 2507 & 2686 & 2466 \\
\hline No. of Observations & 15285 & 12324 & 17094 & 14104 & 14211 & 11322 \\
\hline \multicolumn{7}{|c|}{ Panel B: Cross-Section Results } \\
\hline & \multicolumn{2}{|c|}{$(1)$} & \multicolumn{2}{|c|}{ (4) } & \multicolumn{2}{|c|}{ (5) } \\
\hline & $\mathbf{a}$ & b & $\mathbf{a}$ & b & $\mathbf{a}$ & b \\
\hline BANK CREDIT & $\begin{array}{l}2.6000^{*} * * \\
(06420)\end{array}$ & $\begin{array}{l}2.1000^{* *} \\
(0.8260)\end{array}$ & $\begin{array}{l}2.4300^{* 4 *} \\
(0.6210)\end{array}$ & $\begin{array}{l}2.2300^{* \cdots *} \\
(0.7930)\end{array}$ & $\begin{array}{l}2.5800^{* * *} \\
(0.6170)\end{array}$ & $\begin{array}{l}2.3700^{* * *} \\
(0.7960)\end{array}$ \\
\hline MARKET & 0.1690 & 0.6760 & -0.3240 & 08510 & -0.8370 & 0.0065 \\
\hline CAPITALIZATION & $(0.4820)$ & $(06490)$ & $(05120)$ & $(0.7790)$ & $(05160)$ & $(0.8720)$ \\
\hline CONCENTRATION & $\begin{array}{l}5.5400^{* * *} \\
(0.9960)\end{array}$ & $\begin{array}{l}2.5100^{*} \\
(1.4200)\end{array}$ & & & $\begin{array}{l}6.1500^{* * *} \\
(0.9980)\end{array}$ & $\begin{array}{l}3.3100^{*} * \\
(1.6600)\end{array}$ \\
\hline PUBLIC BANKS & & & $\begin{array}{l}0.0191 * * \\
(0.0082)\end{array}$ & $\begin{array}{l}0.0002 \\
(00012)\end{array}$ & $\begin{array}{l}-0.0352^{\circ} \\
(0.0085)\end{array}$ & $\begin{array}{l}-00171 \\
(0.0147)\end{array}$ \\
\hline $\mathbf{R}^{2}$ & 0.0568 & 0.07 & 0.0464 & 0.07 & 0.06 & 0.06 \\
\hline No. of Firms & 2961 & 2861 & 2737 & 2637 & 2737 & 2637 \\
\hline No. of Observations & 2961 & 2861 & 2737 & 2637 & 2737 & 2637 \\
\hline
\end{tabular}

, ** and ${ }^{*+*}$ indicate significance levels of 10,5 and 1 percent respectively. 


\section{Table V \\ Determinants of Firm Size: Legal Efficiency and Creditor Rights}

The regression equation estimated is: SIZE $=\forall+\exists_{1}$ NFATA $+\exists_{2}$ NSNFA $+\exists_{3}$ ROA $+\exists_{4}$ GDP $+\exists_{5}$ GDP/CAP $+\exists_{6}$ INFLATION $+\exists_{7}$ OPENNESS $+\exists_{9}$ EDUCATION $+\exists_{9}$ BANK CREDIT $+\exists_{10}$ MARKET CAPITALIZATION $+\exists_{11}$ LAW \& ORDER $+\exists_{12}$ LAW \& ORDERXCREDITOR RIGHTS $+\exists_{13}$ CREDITOR RIGHTS + ,. Dependent variable, SIZE, is given by total assets of the firm divided by GDP NFATA is the net fixed assets divided by total assets. NSNFA is the net sales divided by net fixed assets. ROA is return on assets. GDP is given in billions of U.S. dollars. GDP/CAP is real GDP per capita in USS. INFLATION is the log difference of the Consumer Price Indicator. OPENNESS is given by imports plus exports divided by GDP. EDUCATION is gross enrolment in secondary schools. BANK CREDIT is bank credit extended to the private sector divided by GDP. MARKET CAPITALIZATION is stock market capitalization divided by GDP. LAW \& ORDER, scored 1 to 6 , is an indicator of the degree to which citizens of a country are able to utilize the existing legal system to mediate disputes and enforce contracts. CREDITOR RIGHTS is an index that ranges from 0 to 4 and aggregates creditor rights as described in the appendix. In Panel $A$, all regressions are estimated using firm level pooled data over the 1988-1997 period using firm and year random effects. In Panel B, all variables are averaged over the sample period and regressions are estimated including industry dummy variables. Standard errors are given in parentheses. In all specifications coefficients are multiplied by $10^{6}$. Detailed variable definitions and sources are given in the appendix.

\section{Panel A: Panel Results}

(1) (2)

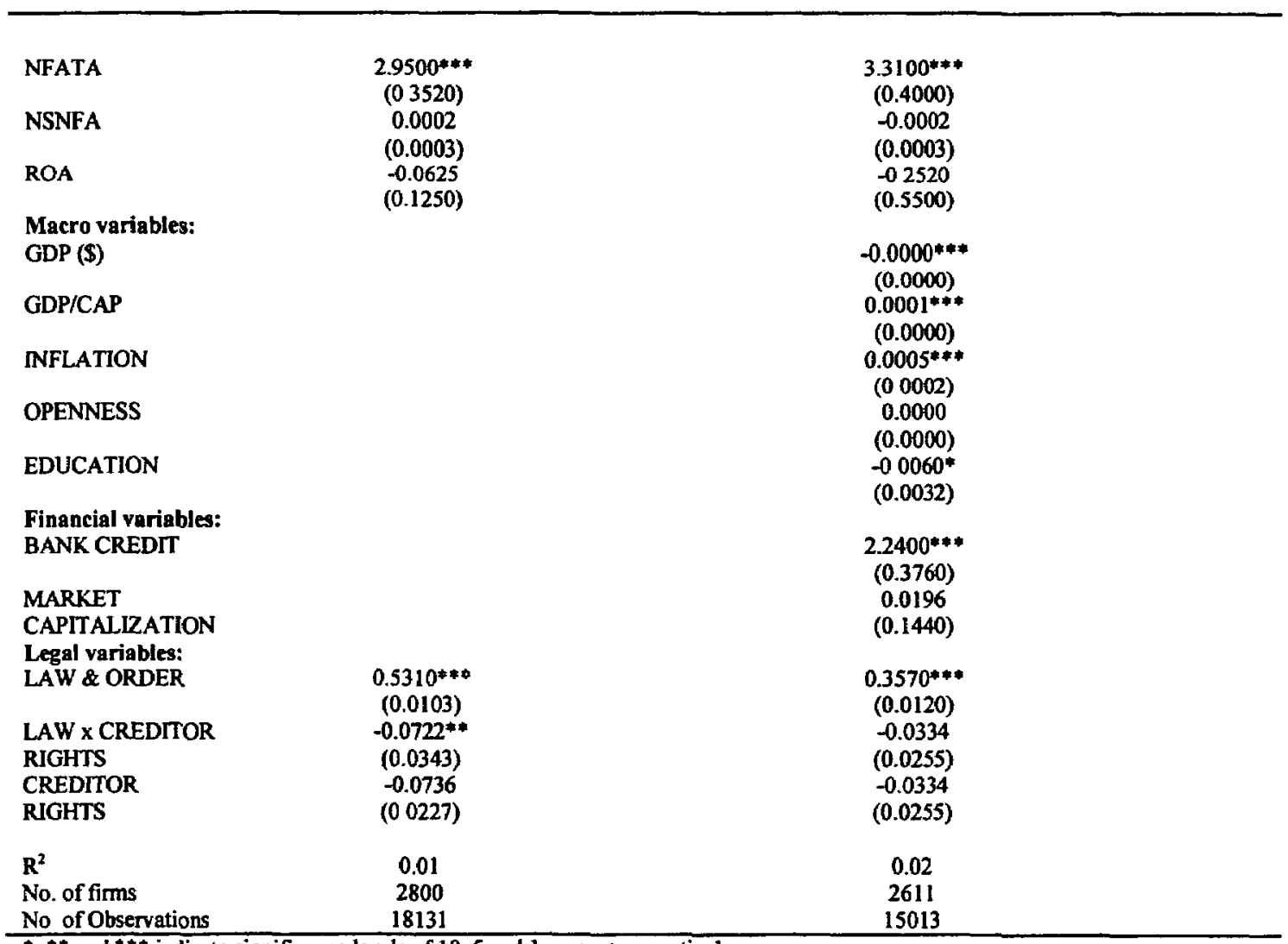

${ }^{*}, *$ and ${ }^{* * *}$ indicate significance levels of 10,5 and 1 percent respectively. 


\section{Panel B: Cross-Section Results}

(1)

(3)

\begin{tabular}{|c|c|c|}
\hline NFATA & $\begin{array}{l}2.3700^{* *} \\
(1.2800)\end{array}$ & $2.6400^{* *}$ \\
\hline NSNFA & $\begin{array}{l}-0.0003 \\
0\end{array}$ & -0.0003 \\
\hline ROA & $\begin{array}{c}0.9380 \\
(2.3600)\end{array}$ & $\begin{array}{l}-0.0108 \\
(2.4300)\end{array}$ \\
\hline $\begin{array}{l}\text { Macro variables: } \\
\text { GDP (\$) }\end{array}$ & & $-0.0000 * * *$ \\
\hline GDP/CAP & & $\begin{array}{l}(0.0000) \\
-0.0001 \\
(0.0001)\end{array}$ \\
\hline INFLATION & & $\begin{array}{l}-0.0004 \\
(0.0011)\end{array}$ \\
\hline OPENNESS & & $\begin{array}{c}0.0022 \\
(0.0047)\end{array}$ \\
\hline EDUCATION & & $\begin{array}{c}0.0505^{* * *} \\
(0.0178)\end{array}$ \\
\hline $\begin{array}{l}\text { Financial variables: } \\
\text { BANK CREDIT }\end{array}$ & & $\begin{array}{c}3.3500^{* 6 * *} \\
(0.9350)\end{array}$ \\
\hline $\begin{array}{l}\text { MARKET } \\
\text { CAPITALIZATION } \\
\text { Legal variable: }\end{array}$ & & $\begin{array}{c}0.4660 \\
(0.7060)\end{array}$ \\
\hline LAW \& ORDER & $\begin{array}{c}0.7940^{* * * *} \\
(0.3100)\end{array}$ & $\begin{array}{c}0.2400 \\
(0.4660)\end{array}$ \\
\hline LAW x CREDITOR & -0.0375 & -0.1800 \\
\hline RIGHTS & $(0.1190)$ & $(0.1390)$ \\
\hline $\begin{array}{l}\text { CREDITOR } \\
\text { RIGHTS }\end{array}$ & $\begin{array}{l}-0.0803 \\
(0.5480)\end{array}$ & $\begin{array}{l}0.1220 \\
(0.6510)\end{array}$ \\
\hline & & 0.07 \\
\hline No. of firms & 2818 & 2718 \\
\hline No of Observations & 2818 & 2718 \\
\hline
\end{tabular}

$*^{* *}$ and ${ }^{* * *}$ indicate significance levels of 10,5 and 1 percent respectively. 


\section{Table VI \\ Sensitivity Tests: Determinants of Firm Size and Financing Constraints}

The regression equation estimated is. SIZE $=\forall+\exists_{1}$ NFATA $+\exists_{2}$ NSNFA $+\exists_{3}$ ROA $+\exists_{4}$ GDP $+\exists_{5}$ GDP/CAP $+\exists_{6}$ INFLATION $+\exists_{7}$ OPENNESS $+\exists_{8}$ EDUCATION $+\exists_{9}$ BANK $+\exists_{10}$ BANK CREDIT ${ }^{*}$ EXFIN $+\exists_{11}$ MARKET CAPITALIZATION+ $\exists_{12}$ MARKET CAPITALIZATION*EXFIN $+\exists_{13}$ EXFIN $+\exists_{14}$ LAW \& ORDER $+\exists_{13}$ LAW \& ORDER*EXFIN $+\exists_{16}$ CRED RIGHTS $+\exists_{17}$ CRED RIGHTS*EXFIN+ ,. Dependent variable, SIZE, is given by total assets of the firm in US S. NFATA is the net fixed assets divided by total assets NSNFA is the net sales divided by net fixed assets ROA is return on assets. GDP is given in billions of U.S doliars. GDP/CAP is real GDP per capita in US\$. INFLATION is the log difference of the Consumer Price Indicator OPENNESS is given by imports plus exports divided by GDP. EDUCATION is gross enrolment in secondary schools. BANK CREDIT is bank credit extended to the private sector divided by GDP MARKET CAPITALIZATION is stock market capitalization divided by GDP. LAW \& ORDER, scored 1 to 6 , is an indicator of the degree to which citizens of a country are able to utilize the existing legal system to mediate disputes and enforce contracts. CREDITOR RIGHTS is an index that ranges from 0 to 4 and aggregates creditor rights. Regressions also include EXFN and interactions of financial and legal variables with EXFIN. EXFIN is the firm level excess growth a la Demirguc-Kunt and Maksimovic (1998) The regression is estimated using firm level pooled data using firm and year random effects Standard errors are given in parentheses. In all specifications coefficients are multiplied by $10^{6}$. Detailed variable definitions and sources are given in the appendix

\begin{tabular}{|c|c|}
\hline NFATA & $\begin{array}{c}2.7500^{* * * *} \\
(0.4360)\end{array}$ \\
\hline NSNFA & $\begin{array}{l}-0.0002 \\
(0.0003)\end{array}$ \\
\hline ROA & $\begin{array}{c}00969 \\
(05820)\end{array}$ \\
\hline \multicolumn{2}{|l|}{ Macro variables: } \\
\hline GDP (\$) & $\begin{array}{c}-0.0005^{* * *} \\
(00001)\end{array}$ \\
\hline GDP/CAP & $\begin{array}{c}00001^{* * * *} \\
(00000)\end{array}$ \\
\hline INFLATION & $\begin{array}{c}0.0006^{* * *} \\
(0.0002)\end{array}$ \\
\hline OPENNESS & $\begin{array}{c}0.0024 \\
(0.0031)\end{array}$ \\
\hline EDUCATION & $\begin{array}{l}-0.0059^{*} \\
(0.0033)\end{array}$ \\
\hline \multicolumn{2}{|l|}{ Financial variables: } \\
\hline BANK CREDIT & $\begin{array}{c}2.2900^{* * *} \\
(0.4000)\end{array}$ \\
\hline BANK CREDIT $x$ EXFIN & $\begin{array}{c}-0.0064 \\
(0.0079)\end{array}$ \\
\hline MARKET CAPITALIZATION & $\begin{array}{c}0.0890 \\
(01460)\end{array}$ \\
\hline MARKET CAPITALIZATION X EXFIN & $\begin{array}{c}00608^{* * *} \\
(0.0024)\end{array}$ \\
\hline EXFIN & $\begin{array}{c}1.6800^{* * *} \\
(0.6210)\end{array}$ \\
\hline \multicolumn{2}{|l|}{ Legal variables: } \\
\hline LAW \& ORDER & $\begin{array}{c}0.1940^{* * *} \\
(0.0589)\end{array}$ \\
\hline LAW $x$ EXFIN & $\begin{array}{c}00048^{* * *} \\
(0.0020)\end{array}$ \\
\hline CRED. RIGHTS & $\begin{array}{c}-0.5530^{* * *} \\
(01970)\end{array}$ \\
\hline CRED. RTS $x$ EXFIN & $\begin{array}{c}-00170^{* * *} \\
(00036)\end{array}$ \\
\hline $\mathbf{R}^{2}$ & 0.02 \\
\hline No of firms & 2448 \\
\hline No. of Observations & 12653 \\
\hline
\end{tabular}




\section{Table VII \\ Sensitivity Tests: Definition of Size}

This table replicates the results in Table III, defining the size variable, SIZE, as total assets of the firm in US $\$$ The regression equation estimated is. SIZE $=\forall+\exists_{1}$ NFATA $+\exists_{2}$ NSNFA $+\exists_{3}$ ROA $+\exists_{4}$ GDP $+\exists_{5}$ GDP/CAP $+\exists_{6}$ INFLATION $+\exists_{7}$ OPENNESS + $\exists_{8}$ EDUCATION $+\exists_{9}$ BANK CREDIT $+\exists_{10}$ MARKET CAPITALIZATION $+\exists_{11}$ LAW \& ORDER+ ,. NFATA is the net fixed assets divided by total assets. NSNFA is the net sales divided by net fixed assets ROA is retum on assets GDP is given in billions of U S. dollars. GDP/CAP is real GDP per capita in USS INFLATION is the log difference of the Consumer Price Indicator. OPENNESS is given by imports plus exports divided by GDP EDUCATION is gross enrolment in secondary schools BANK CREDIT is bank credit extended to the private sector divided by GDP. MARKET CAPITALIZATION is stock market capitalization divided by GDP. LAW \& ORDER, scored 1 to 6 , is an indicator of the degree to which citizens of a country are able to utilize the existing legal system to mediate disputes and enforce contracts. Specifications $(1-3)$ enter groups of variables separately Specification (4) is the full model. In Panel A, all regressions are estimated using firm level pooled data over the 1988-1997 period using firm and year random effects. In Panel B, all variables are averaged over the sample period and regressions are estimated including industry dummy variables Standard errors are given in parentheses In all specifications coefficients are multiplied by $10^{6}$ Detailed variable definitions and sources are given in the appendix.

Panel A: Panel Results

\begin{tabular}{|c|c|c|c|c|}
\hline & (1) & (2) & (3) & (4) \\
\hline NFATA & $\begin{array}{c}07941^{* * * *} \\
(0.2453)\end{array}$ & $\begin{array}{c}09582^{* * *} \\
(0.2669)\end{array}$ & $\begin{array}{c}0.7854^{* * * *} \\
(02579)\end{array}$ & $\begin{array}{c}0.8103^{* * *} \\
(02536)\end{array}$ \\
\hline NSNFA & $\begin{array}{l}-0.0001 \\
(00002)\end{array}$ & $\begin{array}{l}-0.0001 \\
(0.0002)\end{array}$ & $\begin{array}{l}-00002 \\
(0.0002)\end{array}$ & $\begin{array}{l}-0.0001 \\
(0.0002)\end{array}$ \\
\hline ROA & $\begin{array}{l}-0.4743 \\
(03328)\end{array}$ & $\begin{array}{l}-0.0718 \\
(00946)\end{array}$ & $\begin{array}{l}-0.0565 \\
(00920)\end{array}$ & $\begin{array}{c}-0.2343 \\
(03472)\end{array}$ \\
\hline \multicolumn{5}{|l|}{ Macro variables: } \\
\hline GDP (\$) & $\begin{array}{c}0.0025^{* * *} \\
(0.0001)\end{array}$ & & & $\begin{array}{c}00025^{* * *} \\
(0.0001)\end{array}$ \\
\hline GDP/CAP & $\begin{array}{l}0.0001^{* * * *} \\
(00000)\end{array}$ & & & $\begin{array}{c}0.0001^{* * *} \\
(00000)\end{array}$ \\
\hline INFLATION & $\begin{array}{c}00000 \\
(0.0001)\end{array}$ & & & $\begin{array}{c}00000 \\
(0.0001)\end{array}$ \\
\hline OPENNESS & $\begin{array}{l}-00014 \\
(0.0016)\end{array}$ & & & $\begin{array}{l}-00019 \\
(0.0018)\end{array}$ \\
\hline EDUCATION & $\begin{array}{l}-00017 \\
(0.0019)\end{array}$ & & & $\begin{array}{l}-00023 \\
(00020)\end{array}$ \\
\hline $\begin{array}{l}\text { Financial variables: } \\
\text { BANK CREDIT }\end{array}$ & & $\begin{array}{c}22025^{* * *} \\
(0.2239)\end{array}$ & & $\begin{array}{c}1.0455^{* * *} \\
(02394)\end{array}$ \\
\hline $\begin{array}{l}\text { MARKET } \\
\text { CAPITALIZATION }\end{array}$ & & $\begin{array}{l}01386^{*} \\
(00855)\end{array}$ & & $\begin{array}{c}-0.1938^{* *} \\
(00891)\end{array}$ \\
\hline $\begin{array}{l}\text { Legal variable: } \\
\text { LAW \& ORDER }\end{array}$ & & & $\begin{array}{l}0.4492^{* * * *} \\
(00309)\end{array}$ & $\begin{array}{l}0.0769^{* *} \\
(0.0345)\end{array}$ \\
\hline $\begin{array}{l}R^{2} \\
\text { No. of firms } \\
\text { No of Observations }\end{array}$ & $\begin{array}{r}0.18 \\
2746 \\
15925 \\
\end{array}$ & $\begin{array}{r}002 \\
2950 \\
18581 \\
\end{array}$ & $\begin{array}{r}0.01 \\
2943 \\
18468 \\
\end{array}$ & $\begin{array}{r}0.18 \\
2726 \\
15252 \\
\end{array}$ \\
\hline
\end{tabular}

*** and *** indicate significance levels of 10,5 and 1 percent respectively. 
Prmel B3: Cross-Section Resulis

\begin{tabular}{|c|c|c|c|c|}
\hline & (1) & (2) & (3) & (4) \\
\hline NFATA & $\begin{array}{l}-0.3126 \\
(0.9286)\end{array}$ & $\begin{array}{c}-2.0452 \\
(0.9641)\end{array}$ & $\begin{array}{l}-1.3675 \\
(0.9629)\end{array}$ & $\begin{array}{l}-0.3595 \\
(0.9329)\end{array}$ \\
\hline NSNFA & $\begin{array}{l}-0.0001 \\
(00004)\end{array}$ & $\begin{array}{l}-0.0002 \\
(0.0005)\end{array}$ & $\begin{array}{l}-0.0003 \\
(0.0005)\end{array}$ & $\begin{array}{c}0.0001 \\
(00004)\end{array}$ \\
\hline ROA & $\begin{array}{c}-1.3311 \\
(1.7126)\end{array}$ & $\begin{array}{l}-3.0297 \\
(1.8139)\end{array}$ & $\begin{array}{l}-2.4649 \\
(1.8009)\end{array}$ & $\begin{array}{c}-1.4423 \\
(1.7181)\end{array}$ \\
\hline $\begin{array}{l}\text { Macro yariables: } \\
\text { GDP (\$) }\end{array}$ & $0.0024^{\circ+\infty}$ & & & $0.0024^{\text {pos }}$ \\
\hline GDP/CAP & $\begin{array}{c}(0.0001) \\
0.0001 \\
(0.0000)\end{array}$ & & & $\begin{array}{c}(0.0002) \\
0.0001 \\
(0.0001)\end{array}$ \\
\hline INFLATION & $\begin{array}{c}-0.0007 \\
(0.0007)\end{array}$ & & & $\begin{array}{l}-0.0002 \\
(0.0008)\end{array}$ \\
\hline OPENNESS & $\begin{array}{l}-0.0023 \\
(0.0024)\end{array}$ & & & $\begin{array}{l}-0.0049 \\
(0.0030)\end{array}$ \\
\hline EDUCATION & $\begin{array}{c}0.0050 \\
(0.0111)\end{array}$ & & & $\begin{array}{c}0.0146 \\
(0.0118)\end{array}$ \\
\hline $\begin{array}{l}\text { Financial variabies: } \\
\text { BANK CREDIT }\end{array}$ & & $\begin{array}{c}3.3396^{\circ} \\
(0.5081)\end{array}$ & & $\begin{array}{c}1.6996^{\circ 00} \\
(0.6009)\end{array}$ \\
\hline $\begin{array}{l}\text { MARKET } \\
\text { CAPITALIZATION } \\
\text { Legal variables: }\end{array}$ & & $\begin{array}{l}-0.4675 \\
(0.3813)\end{array}$ & & $\begin{array}{c}0.2147 \\
(0.4714)\end{array}$ \\
\hline LAW \& ORDER & & & $\begin{array}{l}1.1220^{\circ 00} \\
(0.1306)\end{array}$ & $\begin{array}{l}-0.2535 \\
(0.2758)\end{array}$ \\
\hline $\begin{array}{l}\mathbf{R}^{2} \\
\text { No of firms } \\
\text { No of Observations }\end{array}$ & $\begin{array}{l}0.22 \\
2863 \\
2863\end{array}$ & $\begin{array}{l}0.07 \\
2963 \\
2963\end{array}$ & $\begin{array}{l}0.07 \\
2963 \\
2963\end{array}$ & $\begin{array}{l}023 \\
2863 \\
2863\end{array}$ \\
\hline
\end{tabular}

${ }^{*}$ and indicate significance levels of 10,5 and 1 percent respectively. 
Appendix. Table A1.

\section{Number of Firm Level Observations in Each Country}

The data source for firm level variables is WorldScope.

\begin{tabular}{|c|c|c|}
\hline & Number of Firm Observations & Number of Firms \\
\hline$\overline{\text { Argentina }}$ & 170 & 17 \\
\hline Australia & 760 & 76 \\
\hline Austria & 570 & 57 \\
\hline Belgium & 580 & 58 \\
\hline Brazil & 990 & 99 \\
\hline Canada & 1000 & 100 \\
\hline Chile & 340 & 34 \\
\hline China & 780 & 78 \\
\hline Colombia & 150 & 15 \\
\hline Czech Republic & 290 & 29 \\
\hline Denmark & 910 & 91 \\
\hline Finland & 630 & 63 \\
\hline France & 1000 & 100 \\
\hline Germany & 1000 & 100 \\
\hline Greece & 640 & 64 \\
\hline Hong Kong & 1000 & 100 \\
\hline Hungary & 130 & 13 \\
\hline India & 1000 & 100 \\
\hline Indonesia & 790 & 79 \\
\hline Ireland & 240 & 24 \\
\hline Israel & 220 & 22 \\
\hline Italy & 1000 & 100 \\
\hline Japan & 1000 & 100 \\
\hline Korea & 1000 & 100 \\
\hline Malaysia & 1000 & 100 \\
\hline Mexico & 520 & 52 \\
\hline Netherlands & 1000 & 100 \\
\hline New Zealand & 210 & 21 \\
\hline Norway & 560 & 56 \\
\hline Pakistan & 680 & 68 \\
\hline Peru & 170 & 17 \\
\hline Philippines & 360 & 36 \\
\hline Portugal & 340 & 34 \\
\hline Singapore & 830 & 83 \\
\hline South Africa & 700 & 70 \\
\hline Spain & 770 & 77 \\
\hline Sweden & 1000 & 100 \\
\hline Switzerland & 980 & 98 \\
\hline Taiwan & 1000 & 100 \\
\hline Thailand & 1000 & 100 \\
\hline Turkey & 430 & 43 \\
\hline United Kingdom & 1000 & 100 \\
\hline United States & 1000 & 100 \\
\hline
\end{tabular}


Table A2

List of lindustries

\begin{tabular}{ll}
\hline Industry & 2-digit SIC \\
\hline Food and Kindred Products & 20 \\
Tobacco Products & 21 \\
Textile Mill Products & 22 \\
Apparel and Other Textile Products & 23 \\
Lumber and Wood Products & 24 \\
Furniture and Fixtures & 25 \\
Paper and Allied Products & 26 \\
Printing and Publishing & 27 \\
Chemical and Allied Products & 28 \\
Petroleum and Coal Products & 29 \\
Rubber and Miscellaneous Plastic Products & 30 \\
Leather and Leather Products & 31 \\
Stone, Clay and Glass Products & 32 \\
Primary Metal Industries & 33 \\
Fabricated Metal Products & 34 \\
Industrial Machinery and Equipment & 35 \\
Electronic and Other Electric Equipment & 36 \\
Transportation Equipment & 39 \\
Instruments and Related Products & \\
Miscellaneous Manufacturing Industries & 28 \\
\hline & \\
\hline
\end{tabular}


Table A3

Variables and Sources

\begin{tabular}{|c|c|c|}
\hline Variable & Definition & Source \\
\hline$\overline{\text { ASSETS/GDP }}$ & Total assets of a firm divided by GDP, both in U.S. dollars & Worldscope \\
\hline $\operatorname{ASSETS}(\$)$ & Total assets of a firm divided by & Worldscope \\
\hline NFATA & Net fixed assets divided by total assets of a firm & Worldscope \\
\hline NSNFA & Net sales divided by net fixed asssets of a firm & Worldscope \\
\hline ROA & Profits divided by total assets of a firm & Worldscope \\
\hline GDP & GDP in constant U.S. dollars & $\begin{array}{l}\text { World Development } \\
\text { Indicators }\end{array}$ \\
\hline GDP/CAP & Real per capita GDP & $\begin{array}{l}\text { World Development } \\
\text { Indicators }\end{array}$ \\
\hline OPENESS & Sum of real exports and imports as share of real GDP & $\begin{array}{l}\text { World Development } \\
\text { Indicators }\end{array}$ \\
\hline INFLATION & Log difference of Consumer Price Index & $\begin{array}{l}\text { International Financial } \\
\text { Statistics (IFS), line } 64\end{array}$ \\
\hline EDUCATION & $\begin{array}{l}\text { Ratio of total enrollment, regardless of age, to the population of the age } \\
\text { group that officially corresponds to secondary education. }\end{array}$ & $\begin{array}{l}\text { World Development } \\
\text { Indicators }\end{array}$ \\
\hline
\end{tabular}


BANK CREDIT

MARKET

CAPITALIZATION

LAW \& ORDER

CREDITOR RIGHTS

CONCENTRATION

PUBLIC BANKS
$\left\{(0.5)^{*}\left[F(t) / P_{-} e(t)+F(t-1) / P_{-} e(t-1)\right]\right\} /\left[G D P(t) / P_{-} a(t)\right]$, where $F$ is credit by deposit money banks to the private sector (lines 22d ), GDP is line 99b, $P_{-} e$ is end-of period CPI (line 64) and $P_{-} a$ is the average CPI for the year.

$\left\{(0.5)^{t}\left[F(t) / P \_e(t)+F(t-1) / P \_e(t-1)\right]\right\} /[G D P(t) / P a(t)]$, where $F$ is the total value of outstanding shares, GDP is line $99 \mathrm{~b}, \mathrm{P}_{-} \mathrm{e}$ is end-of period CPI (line 64) and P_a is the average CPI for the year.

Measure of the law and order tradition of a country. It is an average over 1982-1995. It ranges from 6, strong law and order tradition, to 1, weak law and order tradition.

An index aggregating different creditor rights. The index is formed by adding 1 if: (1) the country imposes restrictions, such as creditors' consent, to file for reorganization; (2) secured creditors are able to gain possession of their security once the reorganization petition has been approved (no automatic stay); (3) secured creditors are ranked first in the distribution of the proceeds that result from the disposition of assets of a bankrupt firm; and (4) the debtor does not retain the administration of its property pending the resolution of the reorganization. The index ranges from 0 to 4 .

Share of assets in largest 10 banks owned by the government as share of total assets of these banks

\author{
IFS
}

IFC Emerging Market

Database and IFS

LLSV (1998)

LLSV (1998)

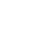






\section{Policy Research Working Paper Series}

Title

WPS2983 Telecommunication Reform in Ghana

WPS2984 Finance and Income Inequality: Test of Alternative Theories

WPS2985 The Impact of Minimum Wages on Employment in a Low Income Country: An Evaluation Using the Difference-in-Differences Approach

WPS2986 Government Bonds in Domestic and Foreign Currency: The Role of Macroeconomic and Institutional Factors

WPS2987 East Asia's Dynamic Development Model and the Republic of Korea's Experiences

WPS2988 Trade Facilitation and Economic Development: Measuring the Impact

WPS2989 Decentralization and Public Services: The Case of Immunization

WPS2990 Ways Out of Poverty: Diffusing Best Practices and Creating CapabilitiesPerspectives on Policies for Poverty Reduction

WPS2991 Tenure Security and Land-Related Investment: Evidence from Ethiopia

WPS2992 Market and Nonmarket Transfers of Land in Ethıopia: Implications for Efficiency, Equity, and Nonfarm Development

WPS2993 Dealing with the Coffee Criss in Central America' Impacts and Strategies

WPS2994 Options for Financing Lifelong Learning

WPS2995 Commodity Market Reform in Africa: Some Recent Experience
Author

Date

March 2003

March 2003

George Clarke

Lixın Colın Xu

Heng-fu Zou

Vivi Alatas

Lisa Cameron

Stijn Claessens

Daniela Klingebiel

Sergıo Schmukler

Ho-Chul Lee

Mary P. McNulty

John S Wilson

Catherıne L Mann

Tsunehıro Otsukı

Peyvand Khaleghian

Michael Kleın

Klaus Deınınger

Songqing Jin

Berhanu Adenew

Samuel Gebre-Selassie

Berhanu Nega

Klaus Deinınger

Songqing Jin

Berhanu Adenew

Samuel Gebre-Selassie

Mulat Demeke

Panos Varangis

Paul Siegel

Daniele Giovannuccı

Bryan Lewin

Miguel Palacios

Takamasa Akiyama

John Baffes

Donald F. Larson

Panos Varangis

March 2003

March 2003

March 2003

March 2003

March 2003

March 2003

March 2003

March 2003

March 2003

March 2003

March 2003
Contact

for paper

P. Sintim-Aboagye

37644

P Sintim-Aboagye

37644

T Maıleı

87347

E. Khıne

37471

$\mathrm{L}$ James

35621

P. Flewitt

32724

H. Sladovich

37698

F Shah

84846

M. Fernandez

33766

M. Fernandez 33766

$P$ Varangıs 33852

E. James

31756

P Kokila

33716 
Policy Research Working Paper Series

Title

WPS2996 Bank Competition, Financing Obstacles, and Access to Credit
Author

Date

March 2003

Thorsten Beck

Asl1 Demirgüç-Kunt

Vojıslav Maksimovic
Contact for paper

K. Labrie 31001 